Education Bureau, Bulletin 1922, no. I2. Dormitories in connection with public secondary schools. 



DEPARTMENT OF THE INTERIOR BUREAU OF EDUCATION

BULLETIN, 1922, No. 12

DORMITORIES IN CONNECTION WITH PUBLIC SECONDARY SCHOOLS

\author{
By \\ EDITH ANNA LATHROP \\ SPECIALIST IN RURAL EDUCATION
} BUREAU OF EDUCATION

WASHINGTON

GOVERNMENT PRINTING OFFICE

1922

क $32: 10$ 
ADDITIONAL COPIES

OF THIS PUBLICATION MAY BE PROCURED FROM

THE SUPERINTENDENT OF DOCUMENTS GOVERNMENT PRINTING OFFICE

WASHINGTON, D. C.

$\Delta \mathbf{T}$

10 CENTS PER COPY 


\section{CONTENTS.}

Chapter I.-Historical development of dormitories with public secondary schools

Page.

Chapter II.-Buildings 5

Chapter III.-Management _..._-_..._.

Chapter IV.-The demand for high-school dormitories and their educational value

Appendix.-Reports from 10 schools

Bibliography

25

36 



\title{
DORMITORIES IN CONNECTION WITH PUBLIC SECONDARY SCHOOLS.
}

\author{
Chapter I. \\ HISTORICAL DEVELOPMENT OF DORMITORIES WITH PUBLIC \\ SECONDARY SCHOOLS.
}

The first secondary schools in the United States were the Latin grammar schools. These were followed by the academies; and the academies, in turn, gave way to the public high schools. In tracing the development of dormitories in connection with public secondary schools it is necessary to determine where private education left off and public education began. It is also necessary to determine the demarcation between elementary courses and secondary courses. No such hard-and-fast rules can be drawn. It is generally accepted, theoretically, that the high schools were the first free public secondary schools, but there were localities in colonial days where the schools were essentially free. Monroe says that from the time of their foundation in 1644 the schools of Dedham, Mass., were free in the modern sense of the term, for they were supported wholly by public taxation. ${ }^{1}$ There were academies whose courses of study more nearly coincided with the modern conception of elementary curricula than those of secondary curricula: The earliest schools in Massachusetts, technically known as free grammar or town schools, imparted secondary as well as elementary education:

As a rule the early schools, both elementary and secondary, received their support from a variety of sources, such as the rental of public lands, tolls from ferries, fish weirs, etc., bequests of land, money, live stock, and slaves, and in nearly all cases from tuition.

Nothing is found concerning dormitories with the Latin grammar schools. These schools were local and prepared for college. The academies came into existence to provide a more liberal education for those who did not want to go to college and for those who did not have secondary school advantages at home. The semipublic academies, which were the recognized institutions of secondary instruction from the Revolutionary days to the middle of the nineteenth century, have been included in this brief historical résume. While they were not public in the sense that we understand public education to-day, they did receive such support from the state as warrants their inclusion in the discussion of public secondary schools.

With academies.-One of the objects in the establishment of the early academies in colonial America was to provide secondary education for those who were not able to secure the same in their home communities. Benjamin Franklin, as early as 1744, in his plan for the establishment of an academy in Philadelphia included provisions for boarders. ${ }^{8}$ However, there is nothing to

1 Monroe, Paul. History of Education, p. 735.

Barnard. Amer. Jour. of Educ., vol. 17, p. 574.

Brown, E. E. The Making of Our Middle Schools, p. 180. 
indicate that the Philadelphia Academy, which was founded in 1749 , ever followed out Franklin's request in this respect, for in the account of the remodeling of the building no mention is made of a dining hall or sleeping compartments. It would seem that the students found homes with the families in the towns, for one of the ends which the academy was expected to serve, set forth by the trustees in their petition for aid from the city treasurer, reads as follows:

It is thought that a good academy erected in Philadelphia, a healthy place, where provisions are plenty, situated in the center of the Colonies, may draw numbers of students from the neighboring provinces, who must spend considerable sums among us yearly in payment for their lodging, diet, apparel, etc., which will be an advantage to our traders, artisans, and owners of houses and lands."

As a rule, the early academies were not provided with facilities for board and lodging, except for a few pupils. ${ }^{\circ}$ An historical sketch of Dummer Academy, Massachusetts, which was founded in 1763, is authority for the fact that Moody, the first principal of the school, persuaded his brother. Joseph to take the mansion house, which with a farm was bequeathed to the institution, and here both he and the boys boarded. ${ }^{5}$ Phillips-Andover and Phillips-Exeter Academies, founded in 1778 and 1781, respectively, did not erect dormitories until a century and a quarter had passed, and then the departure met with much opposition on the part of the townspeople who had depended upon boarding students for a living.

These semipublic academies have, for the most part, given way to the public schools. There are a number of instances, however, especially in the Eastern and Southern States, where these academies are recognized institutions for secondary instruction and, as such receive support from the State or the town or both. Maine has 56 such academies, and 12 of them maintain dormitories. Maryland is aiding three of these secondary schools, each of which has a dormitory. Vermont reports dormitories with some of the academies. Delaware Academy, at Delhi, N. Y., has been assimilated by the public school at Delhi, and the use of the dormitory, which was formerly a part of the academy, is continued as a home for nonresident students.

With state universities.-With the opening of the State universities came, probably, the first opportunity for students to obtain free secondary education as we understand the term "free" to-day. State universities in their early history usually maintained preparatory departments for those whose secondary education was short of college entrance requirements. In some instances dormitories were connected with these early universities. The records of the University of North Carolina, which was opened in 1795 , show that there was a preparatory department in existence in $\mathbf{1 7 9 6}$ and that from the opening until the closing of Caldwell's administration (the first president of the institution) the students "boarded at commons." Mention is also made of the ceaseless efforts of Doctor Caldwell for new buildings to meet the needs of lecture halls and dormitories."

Preparatory departments in the State universities were continued for a long time. Gradually, however, they were discontinued, as the number of high schools increased. As a rule, dormitories have not been provided with State universi-

\footnotetext{
4 Smith, Horace W. Life of William Smith, First Provost of the College and Academy of Philadelphia, p. 52.

5 Adams, Oscar Fay. Some Famous American Schools, pp. 67, 68.

- Cleaveland, Nehemiah. The First Century of Dummer Academy, p. 21.

${ }^{7}$ Smith, Charles Lee. Hist. of Educ. in North Carolina. Clrc. Inf., U. S. Bu. of Educ. No. 3, 1888, pp, 63-69.
} 
ties, probably because of the difficulty in obtaining funds. In Wyoming the preparatory department is included within the practice school of the department of education. About 60 per cent of the girls enrolled in the senior high school come from outside of Laramie, and these live in the college dormitories. The boys in the senior high school live in the town, just as the college men do.

With State normal schools.-With the institution of the State normal schools came another opporturity to obtain "free" secondary education with dormitory accommodations. The first normal school in the United States was opened in 1839 at Lexington (later West Newton), Mass. The next year two more normal schools were established in the State. New York, Pennsylvania, Connecticut, Michigan, and New Jersey soon followed in the footsteps of Massachu. setts. Now every State has one or more State normal schools. The total number in the United States is 184 . The academic work given in these early normal schools was of secondary rather than of collegiate rank. A circular from the State normal school of Albany, N. Y., issued in 1840, states that only those should enter who have a good knowledge of the common branches. ${ }^{8}$ An account of the State Normal School at Bridgewater, Mass., for 1866 in Barnard's American Journal of Education records similar entrance requirements. In fact, at the present time a large percentage of the State normal schools maintain subcollegiate or secondary courses. In some normal schools the practice school includes a high-school department. Where this is the case it is often customary to admit into the practice school students whose secondary education falls short of normal school requirements.

The earliest State normal schools did not maintain dormitories. The State normal school in New Jersey, which opened at Trenton in 1855, found after a few years of operation that the price of board had so increased that it threatened to embarrass the operations of the institution. Accordingly, in 1864 a suitable building was secured and fitted up as a boarding house for female pupils and teachers. By having a considerable number together it was found that the expense to each student could be considerably reduced.' The entrance requirements of the New Jersey normal school at that time were equivalent to a common-school education.

Forty-twơ State normal school presidents maintaining secondary departments and dormitories were corresponded with relative to the admission of secondary students into the dormitories. Thirty replies were received. Twentyeight said that no differentiation was made between secondary and normal students relative to dormitory privileges. Two schools stated that the secondary students were housed in different halls and were subjected to different regulations. Several of the presidents expressed the opinion that this should be done.

With land-grant colleges.-With the passage of the first Morrill Act in 1862 a new impulse was given the State universities, for it was general to turn over to the existing State institutions the funds provided by the congressional act for the purpose of establishing colleges of agriculture and mechanic arts. Some of these colleges still retain schools of secondary grade. In some instances these schools are administered by the college officials and housed in the college buildings. In others they have separate organizations and are located in different parts of the State.

At present the following named States maintain secondary courses in connection with their land-grant colleges and open their college dormitories to students registered in these courses: Connecticut, Iowa, New Mexico, North

${ }^{8}$ Barnard. Amer. Jour. of Educ., vol. 13, 531.

O Ibid., vol. 17, 737. 
Dakota, Oklahoma, Tennessee, Virginia, and Washington. Iowa and South Dakota report dormitory provisions for girls only. North Dakata, Tennessee, and Washington state that their dormitory facilities will care for only a portion of the students. Oklahoma is abolishing the preparatory course one year at a time; two years are gone already.

All of the 17 land-grant colleges for negroes maintain secondary courses and provide dormitories. In fact these institutions are on the whole more nearly of secondary than of collegiate grade. The list of the States where these institutions exist follows: Alabama, Arkansas, Delaware, Florida, Georgia, Kentucky, Louisiana, Maryland, Mississippi, Missouri, North Carolina, Oklahoma, South Carolina, Tennessee, Texas, Virginia, and West Virginia.

The States with secondary schools under a different organization from that of the college, and with dormitories, are California, Colorado, and Minnesota. The Davis Farm School, which is under the management of the board of regents of the University of California, was opened in 1906. The Fort Lewis School, at Hesperus, Colo., has dormitory accommodations for about 30 girls and 30 boys. The Northwest School of Agriculture, at Crookston, Minn., established in 1910, and the West Central School at Morris, Minn., are both a part of the department of agriculture of the University of Minnesota and are under the control of the board of regents.

With independent agricultural high schools.-The independent agricultural high schools represent another type of secondary schools with which dormitories are common. Probably the first dormitories to be erected in connection with independent public high schools in the United States were those erected in conformity with the law passed in Alabama in February, 1889, authorizing the establishment of a branch agricultural experiment station and branch agricultural school in north Alabama. Under this act two schools were organized, one at Athens and one at Abbeville. Similar acts of the legislature brought into existence 10 of these congressional district agricultural high schools. A report of the school at Athens found in the biennial report of the State superintendent for 1892-1894 indicates that a boarding department. was connected with the school at that time. At present only 3 of the 10 district schools maintain dormitories. The legislature of 1919 changed the names of these schools from district agricultural schools and experiment stations to State secondary agricultural schools.

A polytechnic secondary school at San Luis Obispo, Calif., established by a legislative act of 1901, maintains dormitories and is under the management of an independent State board. In 1906 the Legislature of Georgia made provision for congressional district agricultural high schools similar to those of Alabama. The management of each of these schools is under the control of a board of trustees made up of a representative from each county in the congressional district. There are now 12 such schools, and dormitories are maintained in connection with all of them. The first secondary school of agriculture in New York was established in 1906, in connection with St. Lawrence University. Four of the New York secondary schools report dormitories. A bill was before the legislature in 1921 asking for the appropriation of $\$ 75,000$ for erection of dormitories in connection with the school at Morrisville. The first legislature in Okiahoma (1907) created an act for the establishment of secondary schools of agriculture in each judicial district, in conformity with the provisions of the constitution. These schools are largely under the control of the State board of agriculture. There are now four such schools, and dormitories are in connection with all of them. In 1909 a legislative act of Arkansas provided for the maintenance of secondary schools of agriculture. At present there are four 
of these schools, and all have dormitories. Two secondary schools of agriculture in North Dakota maintain dormitories, one in connection with the School of Science at Wahpeton and the other in connection with the School of Forestry at Bottineau. In Vermont a legislative appropriation was made in 1912 for a dormitory in connection with the secondary school of agriculture at Randolph Center. This school is under the management of the State board of education.

In 1910 the General Assembly of the State of Virginia passed an act providing for the instruction of agriculture and domestic science in at least one high school in each congressional district in the State. To make it possible for these schools to function as centers of vocational education for congressional districts, it was found necessary to establish in many of them dormitories for boys and girls. When the State accepted the grants of the Smith-Hughes vocation act it withdrew. its appropriations from the congressional district high schools and permitted them to organize their departments in accordance with the plans of the State board for vocational education. By this act these schools lost their status as congressional district high schools and assumed that of local high schools maintaining departments of vocational agriculture.

County agricultural high schools with dormitories are found in Michigan, Mississippi, and Wisconsin. County agricultural high schools were first established in Wisconsin in 1902. These high schools are built and equipped at the expense of the counties where located, but the State makes a grant of from $\$ 6,000$ to $\$ 8,000$ a year for each school. Two of the schools have dormitories. The Michigan Legislature of 1907 passed an act providing for county agricultural high schools, similar to the act of Wisconsin. Two of these schools report dormitories. The legislature of Mississippi passed an act in 1910 providing for county agricultural high schools. The State now has 51 of these schools, and dormitories are found in connection with all of them.

With farm-life schools of North Carotina.-The county farm-life schools in North Carolina are another type of secondary schools with which dormitories are associated. These schools, like the independent agricultural schools, are located on farms. Five such schools are reported from North Carolina. The State department of education is authority for the statement that these schools have never functioned as real farm-life schools. However, the dormitories do fill a real need in providing a home for rural boys and girls who live long distances from a high school.

With county and district high schools in sparsely settled localities.-Within the past few years there has been a tendency to establish dormitories in connectior with county and district high schools in sparsely settled regions or in localities where transportation is difficult. It has seemed to be the best way to provide high-school education for those who live at distances too great for transportation. The greatest impetus given to this movement has been in the State of Montana, where there are now 25 county and district high schools maintaining dormitories. According to the report of the State superintendent for 1920 , the practicability of dormitories for housing public school children who live far from school was first demonstrated in 1914-15, at the Flathead County High School in Kalispell. A commodious residence was leased by the county school board and transformed into a dormitory for girls. The experiment proved so satisfactory that in 1915-16 a building which had formerly been used for a business college was remodeled for a boys' dormitory. Other States promoting dormitories for localities inaccessible to high school are Oalifornia, Colorado, Nebraska, Nevada, and West Virginia. 
Legal enactments for dormitories.-The Alabama Legislature of 1919 provided that within three years from January 1, 1920, dormitories shall be erected with all the 10 State secondary schools of agriculture. In Nebraska the laws include school dormitories as among the institutions for which precincts, townships, and second-class cities or villages may issue bonds for improvement. The statutes of Mississippi provide that county school boards, whose duty it is to administer county agricultural high schools, shall include among the buildings to be erected for such schools boarding departments where not less than 40 students may have dormitory and dining-room facilities. County school boards in Nevada are empowered by the statutes to provide for rental, purchase, and erection of dormitories and dining halls for county high-school students. The statutes of North Carolina provide that dormitories with suitable accommodations for not less than 25 boys and 25 girls shall be erected in connection with farm-life schools. In West Virginia, district or county school boards may erect, purchase, or lease buildings to be used as dormitories for the accommodation of pupils wishing to attend high school.

Where the legal authority for the erection of dormitories is not specific it is implied by a broad interpretation of the law. For example, such a phrase as " to erect the necessary buildings" may be construed to include dormitories.

Number of dormitories in the United States connected with secondary schools. - The accompanying table shows the number of dormitories in the United States associated with public secondary schools. The table includes the independent agricultural high schools, the farm-life schools of North Carolina, and the county and district high schools. In each instance the unit of control is given. The information given in the table is based upon replies from highschool inspectors in the various States. Secondary schools of agriculture affiliated with land-grant colleges, and housed on the college campus, and secondary departments of universities and normal schools are not included.

TABLE 1.-Number of dormitories in connection with public secondary schools distributed according to control.

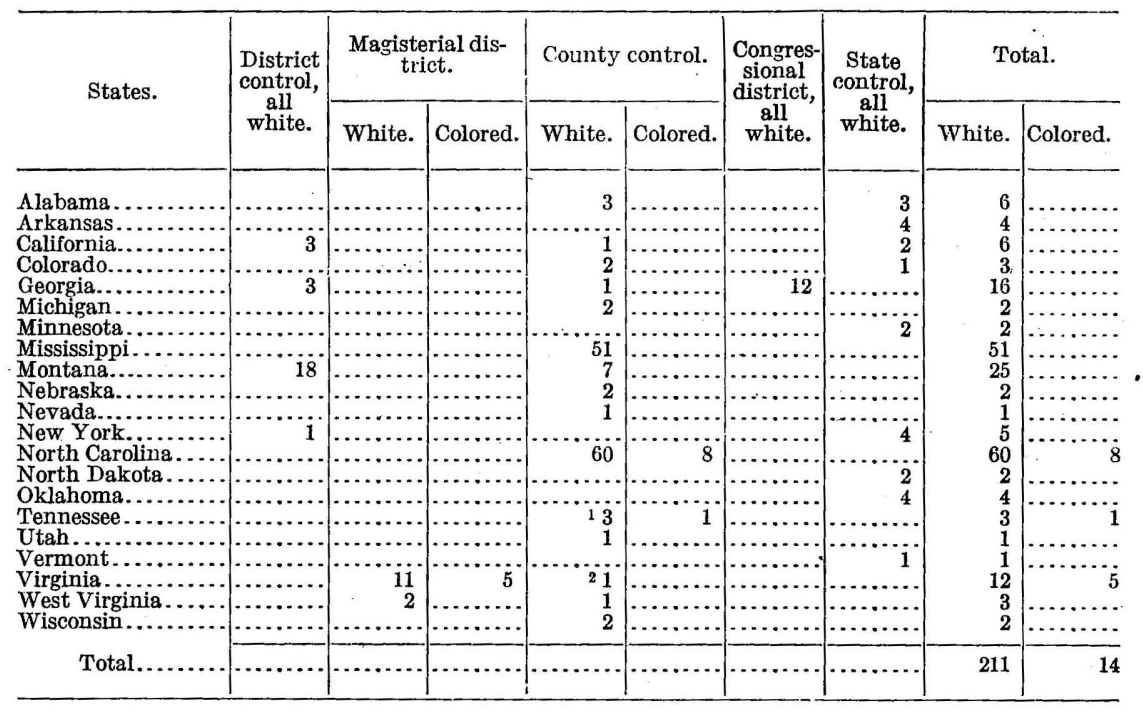

1 Data incomplete; State department unable to supply information.

2 Serves 3 counties. 


\section{Chapter II.}

\section{BUILDINGS.}

This report on buildings, and that on management which follows in the next chapter, are based upon replies from questionnaires from 29 high schools maintaining dormitories throughout the United States. Numerically the distribution is as follows: 3 congressional district agricultural high schools, 7 county agricultural high schools, 3 farm-life schools with secondary departments, 9 county high schools, and 7 local and magisterial district high schools. Geographically they represent schools in California, Georgia, Mississippi, Montana, Nebraska, New York, Nevada, North Carolina, Utah, Virginia, and West Virginia. In 19 instances the report is supplemented by personal visits. All of the schools are for white children with the exception of one of the farmlife schools. A brief report of this school is given in the chapter on "Reports from 10 schools."

Boys' dormitories.-Thirteen of the schools reported in this chapter have built or purchased buildings which are used exclusively for boys' dormitories. In four instances dwelling houses are rented and used as temporary quarters for the boys. In eight schools boys and girls are housed in the same building. In the remaining schools the boys find rooms in private houses. The original cost of the 13 buildings ranges from $\$ 2,500$ to $\$ 26,000$. The median is $\$ 15,500$. The buildings are all comparatively new. Ten were erected between 1906 and 1917 and three since 1917. The length and width of 12 buildings were reported. In terms of medians the dimensions follow: Length 120 feet, width 40 feet. All of the buildings save one are two stories above the basement. Ten are heated by furnaces, two by stoves, and one by corner grates. All are lighted by electricity. Ten dormitories report from one to eight lavatories for each building. Three buildings report one lavatory for each room. From one to nine toilets per building are reported. In 11 buildings there are from 1 to 6 shower baths; 5 buildings report from 5 to 8 tub baths. In 5 of the buildings both shower and tub bath facilities are found. Only two dormitories report hospital provisions. The number of students that can be housed ranges from 20 to 125 . The median is 62 .

Three of the rented buildings are heated by stoves and one by a furnace. All have electric lights. In two there is no plumbing. No hospital provisions are reported, but in one instance the services of a house doctor are provided. From 16 to 25 students can be housed in each of these rented buildings.

Girls' dormitories.-Twenty-eight schools reported. Nineteen of them have provided dormitories exclusively for the girls. The original cost of these buildings ranges from $\$ 500$ to $\$ 55,000$. The median is $\$ 15,000$. All the buildings were built since 1900 , and 12 since 1917. Dimensions of 17 buildings were reported. The median length is 102 feet and the width 40 feet. Four buildings are three stories above the basement and 14 two stories, and 1 one-story. One building is heated by grates, 4 by stoves, and 14 by furnaces. All of the buildings are lighted by electricity. Three buildings report a lava- 
tory for each room, and the remainder from one to eight per building. From 1 to 11 toilets per building are reported. All the buildings are provided with tub baths. The number of tubs per building ranges from one to eight. Seven of the buildings report two. Four buildings report shower baths in addition to the tubs. Five buildings report hospital provisions. These vary; in one instance it is merely an isolated room, in another an isolated room equipped with two hospital beds and an adjoining room for the nurse, and in another a room equipped with first-aid material. The number of students that can be accommodated varies from 12 to 125 . The median is 60 .

This report on the 19 dormitories for girls does not include the dormitory at Delhi, N. Y., as details were not given on the blank. In this school the dormitory is a relic of the old academy. The principal is given the use of the building, and in turn is expected to furnish it and board and lodge out-oftown pupils. At present the building is housing 19 teachers and 7 pupils.

Boys and girls in the same building.-In 8 of the 28 reports both boys and girls are housed in the same building. Three of the buildings were built with the idea of accommodating both sexés. In one instance (Boulder, Mont.) a gymnasium separates the boys' and girls' apartments. At Elko, Nev., the boys' and girls' apartments are separated upstairs by a solid wall and downstairs by the dining hall. In the other instances the dormitories are temporary quarters. The boys occupy the upper floor and the girls the lower. A detailed account of the dormitory at Elko, Nev., is given in a succeeding chapter.

Facilities for laundrying.-A few of the schools have basement rooms equipped with tubs and electric irons, where the students have the privilege of doing their own laundry work. In two of the agricultural schools steam laundries are operated in connection with the schools. All the labor connected with the laundries is performed by the students. In most of the schools a large percentage of the students spend the week-ends at home, thus eliminating the laundry problem.

Dining halls.-Reports were received from 28 of the 29 schools on diningroom facilities. In 16 instances the dining hall is in the girls' dormitory. In the eight cases where both boys and girls occupy the same building it is, of course, given space in that building. In one of the farm-life schools it is in the basement of the schoolhouse, in one school a community dining room. is reported for each building, and in another school the dining hall in the girls' dormitory is not open to the boys. In only one instance is a separate dining hall provided. This building which is in connection with one of the congressional district agricultural schools of Georgia was built in 1914 at a cost of $\$ 7,500$. Its dimensions are 90 feet by 30 feet.

Students' rooms.-As a rule the students' rooms are furnished with heavy material, such as furniture, mattresses, and pillows, and students supply their own dressings for the beds and towels and napkins. In practically every instance the rooms are planned so that two may occupy a room. 'A number of the buildings were so overcrowded that three and sometimes four occupied a single room.

Summary.-In providing dormitories the schools first consider a residence for the girls. In practically all of the schools visited where dormitories existed only for girls, the opinion was expressed that as soon as financial conditions permitted dormitories would be provided for the boys. The general opinion seems to be that it is more satisfactory for girls and boys to be in separate buildings. 
In most of the instances where boys and girls were housed in the same buildings, it was in the temporary buildings. The new buildings were modern, well arranged, and well equipped. On the whole the facilities for bathing were insufficient and there was a general lack of hospital apartments and first-aid appliances. Laundry facilities were usually lacking. There is a demand for steam laundries in the schools located on farms.

As a rule, the dining hall was a part of the giris' dormitory. However, future plans for the largest schools contemplate separate buildings for dining halls. 


\section{Chapter III.}

\section{MANAGEMENT}

Living expenses.-Only one school reports a charge for rooms. In this instance the rates are $\$ 8$ per month for single rooms and $\$ 12$ per month for double rooms. As a rule, light, heat, and water are included in the pro rata charge for meals. Janitor service is usually performed by the students.

Twenty-four schools reported on the cost per week of table board. Of this number, 23 attempt to serve meals at the actual cost of the food, its preparation, and service. In some cases an estimate is set at the beginning of the year as to the probable cost. In others, the amount is prorated at the close of each month. The monthly cost of board ranges from $\$ 8$ to $\$ 25$. The median is $\$ 15$. In a few schools meat and vegetables are purchased from the farmers whose children board in the dormitories. In the congressional district and county agricultural high schools of the South the monthly rate of board is usually below $\$ 15$. This is due to the fact that a considerable portion of the food is produced on the school farms and that the students perform much of the labor. Thirteen schools reported a deficit during the school year 1919-20. The largest deficit reported was $\$ 703.94$. These deficits came about in schools that had set the - price of board at the beginning of the year. They had failed to anticipate the increase in the cost of food. In 9 of the 13 schools the school board provided for the deficit either by an increased levy or by including it in the next year's food budget. In the remaining 4 schools the parents of boarding students were asked to make up the difference.

Student labor.-Eighteen schools reported that the boys have an opportunity to earn something toward defraying their living expenses. These duties include janitor services, laundrying, caring for live stock and crops. The amount paid for labor varies from 15 cents per hour to $\$ 50$ per month. The number of boys performing labor varies from 1 to 92 (the entire enrollment). The median is 12 .

Fifteen of the schools report that the girls have opportunity to earn something toward defraying their expenses. The duties performed by the girls are cooking, waiting on tables, washing dishes, sweeping, laundrying, and library work. The amount paid varies from 15 cents per hour to $\$ 20$ per month. The number of girls performing such duties varies from 2 to 31 . The median is 9 .

In all the congressional district and county agricultural schools of the South at least one hour a day of manual labor is required of each pupil. The Carbon County High School at Price, Utah, requires all students to participate in the care of the dormitories. The same is true of one of the girls' dormitories visited in Montana. For such duties in the schools enumerated above the students receive no pay. Abundant opportunity is found in the congressional district and county high schools for "work for pay" outside of the one hour per day required of every student. Of course, the schools that maintain farms offer abundant opportunity for student labor, especially for the boys.

Supervision.-The number of mature persons responsible for the conduct of the students varies from 1 to 11 . From boys' dormitories 22 reports were 
received, and 27 from girls' dormitories. The median number of supervisors in each instance is two. The duties of these supervisors are varied. Usually in the boys' dormitories it is customary to furnish two or more men teachers living quarters in the building. These men are supposed to act as general advisers to the boys and to enforce the rules and regulations. The Carbon County High School in Utah designates the man in charge as "preceptor." Two men under his supervision direct the study and social and religious activities. In this school the duties of the supervisors are specifically stated. However, as a rule they were not, and from the appearance of many of the boys' dormitories they were loosely enforced.

The woman in charge of the girls' dormitories is generally designated as " matron." Her duties are varied, depending upon the size and organization of the dormitory. At Stanford, Mont., she was buyer, cook, bookkeeper, disciplinarian, and friend. In some instances all the women teachers rooming in the dormitory are given some supervisory duties. Usually this consists of general oversight of a number of rooms, which really amounts to the enforcement of the rules regarding study for the girls occupying these rooms. In a number of the dormitories the principal of the school and his family have living quarters in the girls' dormitories. This is especially true of the congressional district and county high schools. In these schools the principal of the school does the buying for the institution, and his wife performs the office of matron.

Self-government.-Reports were received from 24 schools on student government. Thirteen of these schools say that practically no attempt whatever is made in that direction. In one of these schools the boys are under semimilitary regulations. In another the answer to the questionnaire was, "behave or go home." From the answers and from personal interviews, it would seem that these schools are not in sympathy with self-government.

Only five of the schools reporting self-government either wholly or in part give any organized plans. The congressional district agricultural high school at Powder Springs, Ga., has a student court for both boys and girls which meets every Friday night. All cases that are not a direct infringement of school laws are tried in this court. The members of the faculty are always present at these hearings-the men meeting with the boys and the women with the girls. At Lewistown, Mont., the girls of the dormitory have formed a club which meets at stated intervals to discuss all matters pertaining to right ethical standards in dormitory mañagement. At Elko, Nev., the school is organized on a city plan, with a mayor, commissioners, judge, attorney, and police. All cases are tried in this court. The Berry O'Kelly Negro Training School, at Method, N. C., has a student committee on discipline. The Farm Life School, at Cary, N. C., has a student council made up of representatives from the various school groups. On the day that the school was visited, this council had to deal with a case of hazing at the boys' dormitory. Details concerning this council are given in the chapter including reports of individual schools.

Rules and regulations.-Most of the schools have the rules and regulations printed in the school catalogues. The following set of rules printed in the 1920 bulletin of the Forrest County Agricultural High School at Brooklyn, Miss., is typical of dormitory rules in general.

\section{ABSTRACT OF REGULATIONS AND SUGGESTIONS.}

The only real rule necessary for any school is " Do right," but in our experience we have learned that any well-regulated school must have some rules for the protection of both student body and faculty. We have to be more specific with some than with others; hence the necessity of outlining a few regulations that must be adhered to by all. 
1. Discipline will be strict and impartial; kind yet firm. Plenty of tact and judgment will be exercised in dealing with all cases.

2. This school is not primarily a reformatory nor a jail. Our time is valuable; hence we have no place for the rough and rowdy, who have no desire to be taught.

3. No student who persists in disobedience or fails to perform work assigned him, or who is exercising a bad influence upon the school, will be permitted to remain here.

4. Pupils must be prompt and regular in attendance at school, recitation, and other exercises of the school.

5. Idleness, profanity, or cigarette smoking will not be tolerated. Pupils must study and work.

6. Pupils must replace or pay for all articles broken or damaged in room or buildings for" which they are responsible.

7. Do not drive tacks or nails in the wall. Abuse of rooms or buildings will not be tolerated.

8. Keep room clean and orderly at all times. It will be inspected daily at a regular hour in the morning and at such other time as may seem best by members of the faculty or matron. Pupils will be graded on neatness.

9. Boys having sisters in the girls' home or girls having brothers or other relatives in the boys' home will not be permitted to visit them in their rooms except in case of serious illness, and will not be allowed in the building at any time without the permission of the matron.

10. Pupils will not be allowed to attend any entertainment given away from school without the approval of the principal. Parties and the like are demoralizing to pupils. Parents, resident and nonresident, will please cooperate with us to discourage all things that tend to detract from the school work. Social privileges will be allowed pupils at the proper time and place under the direct supervision of the faculty.

11. Pupils having parents or guardians must get a written permit to go home or leave school to visit relatives or friends away from school. Parents will please use the best of judgment in giving permits. Do not make them too general. All permits must be mailed to the principal.

12. Pupils may go home on the Fridays that close each six-week term, but at no other time unless there is serious illness in the family.

13. Pupils must not leave the campus without permission of that member of the faculty in charge. Certain days will be set apart by the faculty for students to go to town. At no time are pupils to remain off the campus at meal time or at night without special permission.

14. The mere fact that a pupil enters this school and has his name enrolled is an agreement that he will obey all rules and regulations for the school now or hereafter placed in force.

15. Pupils will be required to observe regular hours. First, all vacant periods during the day under the observation and help of a member of the faculty in class or study room. Second, at least two hours at night in his own room. Students are not allowed to visit rooms during study hours or to be out in the halls. Everybody must be perfectly quiet in the buildings during study periods and at all other times.

Social and religious activities.-Practically all of the schools assume more or less responsibility of matters pertaining to the social and religous welfare of the students. Where dancing is permitted, it is chaperoned by members of the faculty. Usually the rules regarding dances are few and indefinite. The most explicit are those found in the report of the Powell County High School, at Deor Lodge, Mont. As a rule, dancing is not permitted in the schools of the South. In these schools it is common to find "social hours" once or twice a week where both boys and girls are together. These events are chaperoned. Lyceum courses, school parties, literary societies, and the usual athletic games, such as baseball, basket ball, football, and tennis, are common in all the schools,

In a few schools students are required to attend the church of their choice on Sunday mornings. Other schools urge that this be done, but do not make it compulsory. Where the schools are situated several miles from town, religious: services are held on Sundays at the schools. One superintendent expressed the opinion that the dormitory students were a stimulus to the local churches 


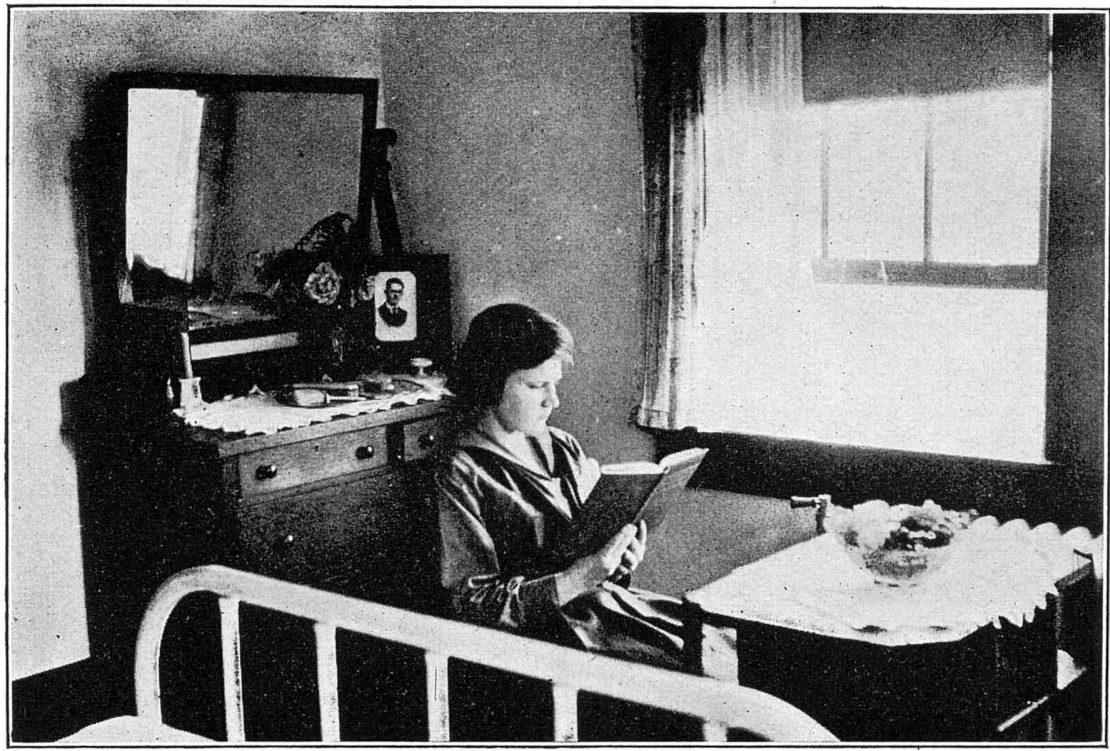

A. A STUDENT'S ROOM, GIRLS' DORMITORY, FIFTH CONGRESSIONAL DISTRICT AGRICULTURAL HIGH SCHOOL, MONROE, GA.

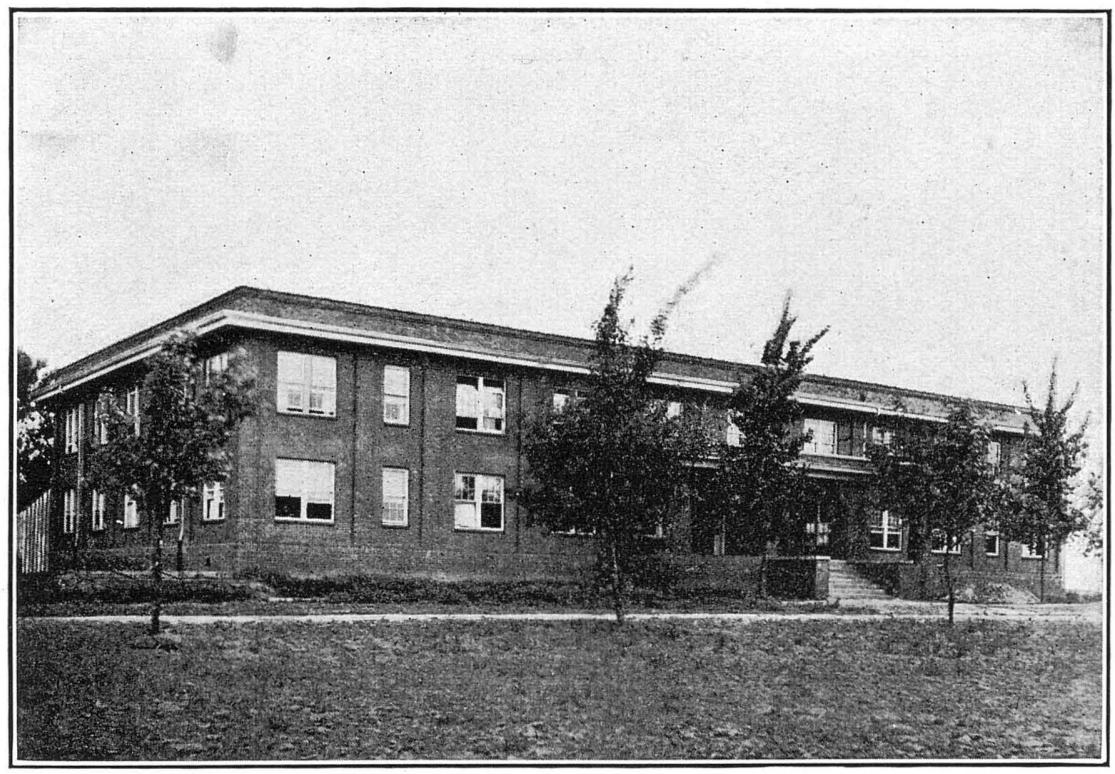

B. NEW GIRLS' DORMITORY, FIFTH CONGRESSIONAL DISTRICT AGRICULTURAL HIGH SCHOOL, MONROE, GA. 


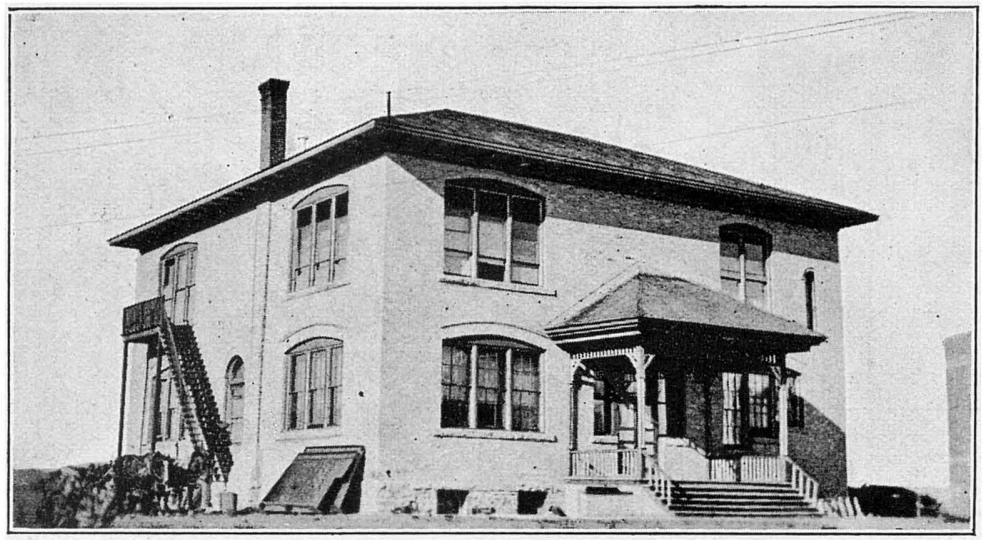

A. AN OLD SCHOOLHOUSE REMODELED FOR A GIRLS' DORMITORY, CHOTEAU, MONT.

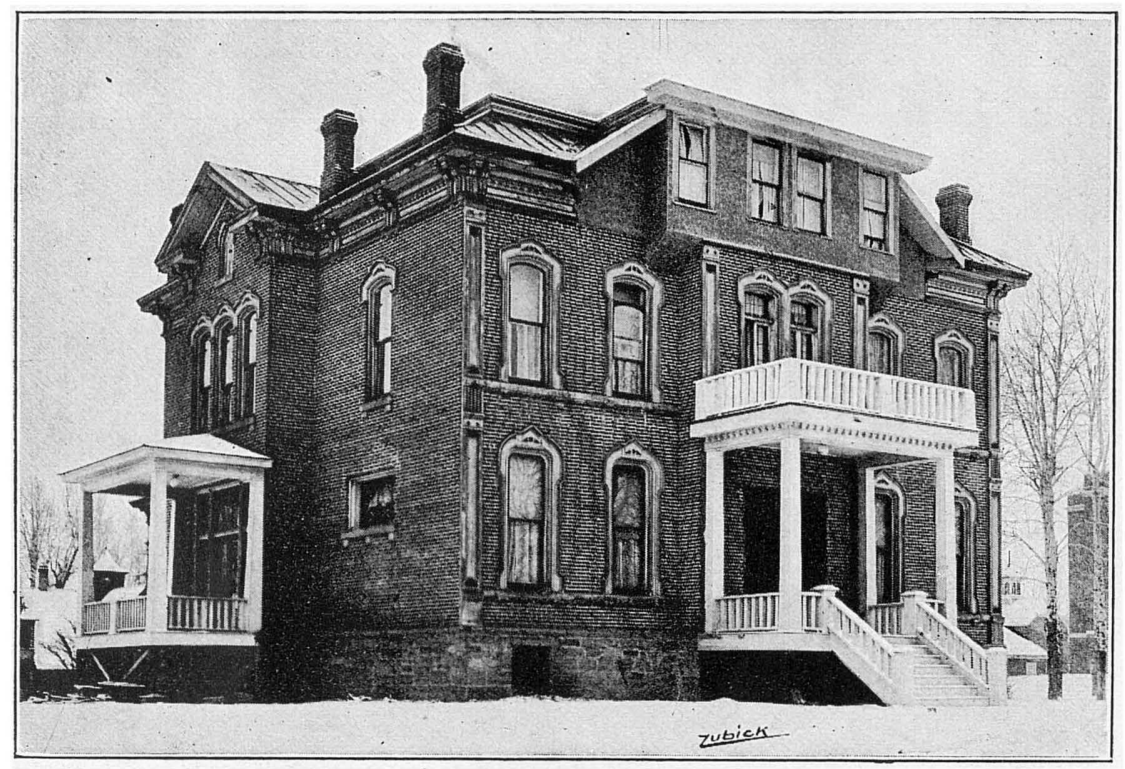

B. GIRLS' DORMITORY, POWELL COUNTY HIGH SCHOOL, DEER LODGE, MONT. Former home of a mining magnate. 


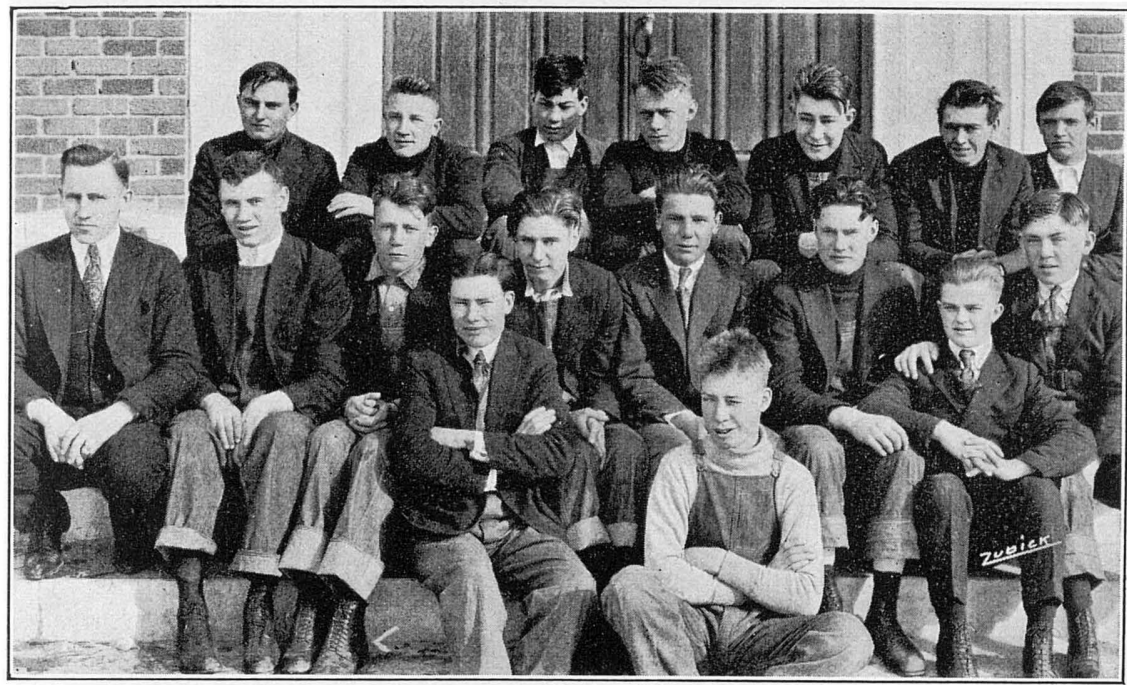

A. AN AGRICULTURAL CLASS IN A MONTANA COUNTY HIGH SCHOOL. Of these 17 boys, 15 come from ranches; 9 of the 15 live in the boys' dormitory; 6 live with
their families, who have moved into town for the school season.

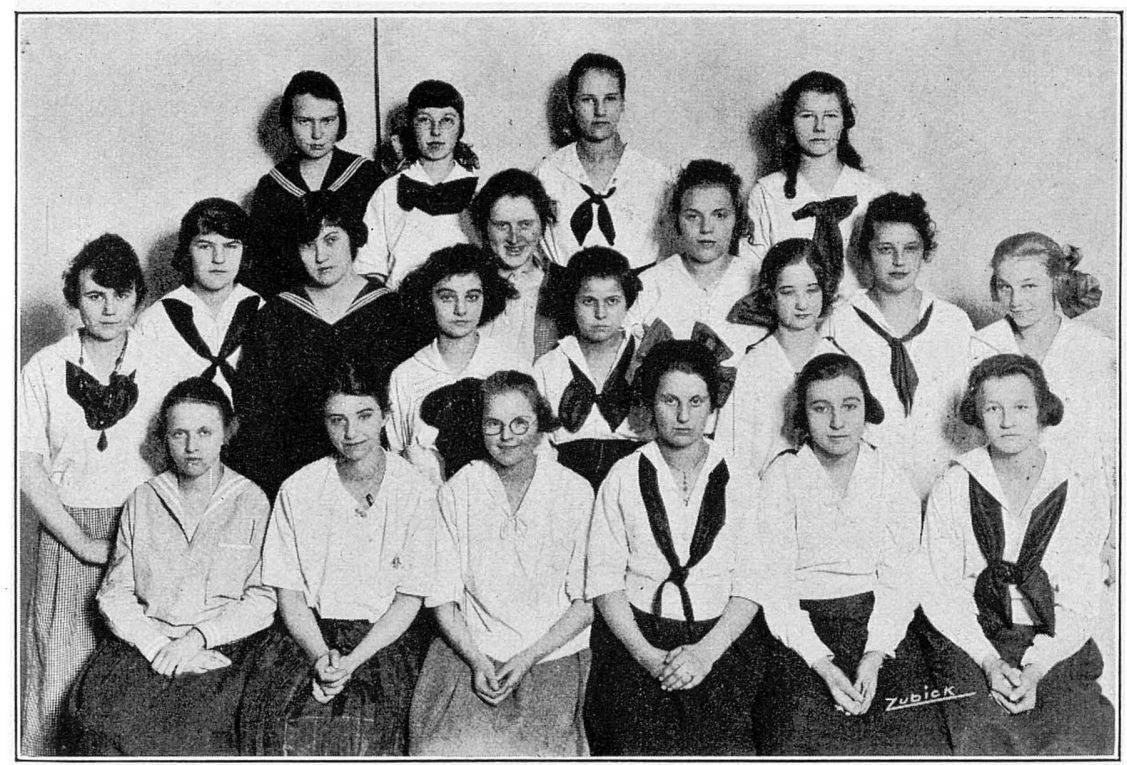

B. A HOME ECONOMICS CLUB.

Some Montana dormitory girls who have organized a club to promote a larger interest in home making. 


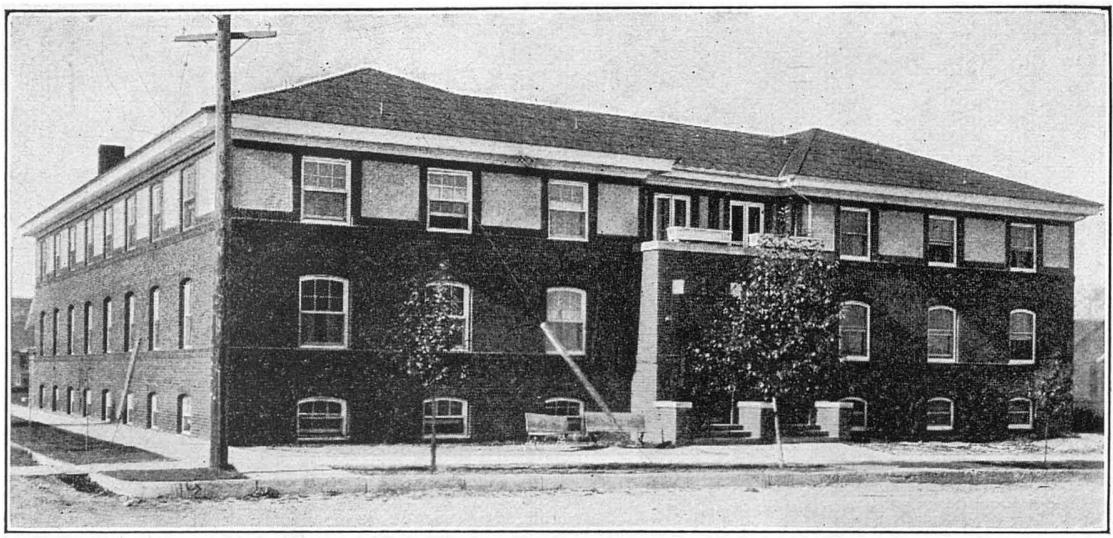

A. GIRLS' DORMITORY, FERGUS COUNTY HIGH SCHOOL, LEWISTOWN, MONT. Built by the Commercial Club of Lewistown.

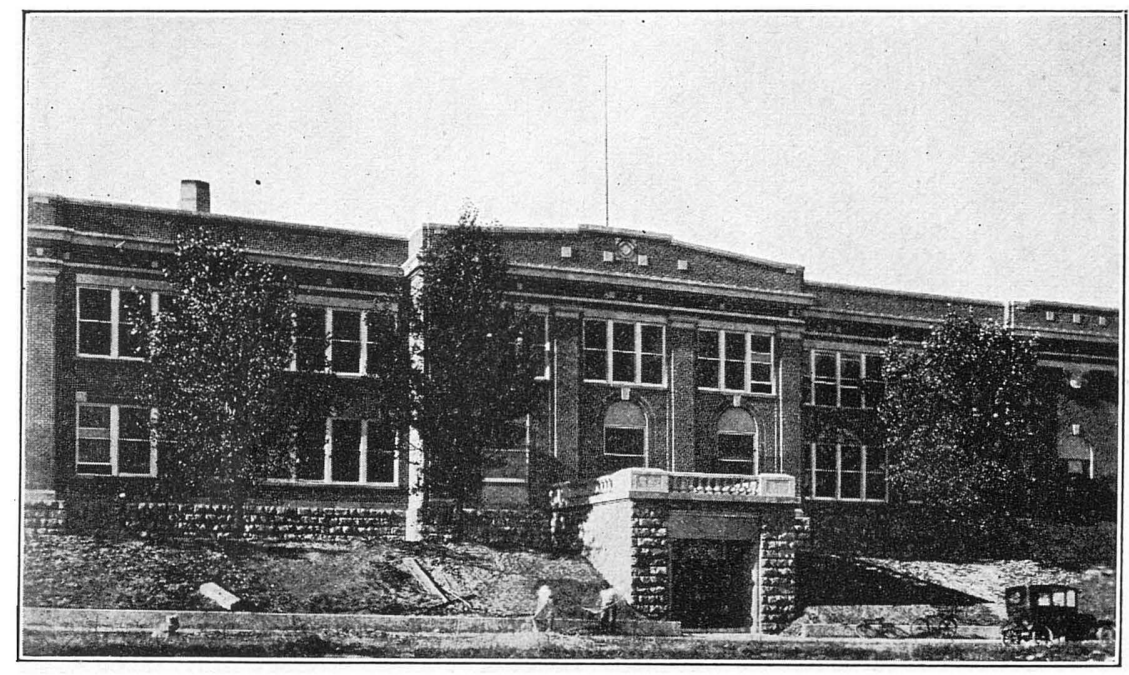

B. FERGUS COUNTY HIGH SCHOOL, LEWISTOWN, MONT, 
because of the help they gave to the Sunday schools and the young people's societies. Y. M. C. A. and Y. W. C. A. organizations were found in some schools. Summary.-As a rule, no charge is made for rooms; and the price for table board is usually put on a cost basis. In most schools the students must assume some duties relative to the care and upkeep of the dormitories. In practically every school there is an opportunity for the students to earn something toward defraying their own expenses. Where schools are located on farms, these chances are mant, especially for the boys. Members of the faculty serve as preceptors for the boys. The matrons are usually outside the faculty. More than half of the schools believe in some form of student government. However, only a few schools have any well-organized plans in this direction. The rules and regulations concerning dormitory life are usually printed in the school catalogue. As a rule, they are definite and explicit. Most schools give considerable attention to the social and religious welfare of the students.

$95251^{\circ}-22-2$ 


\section{Chapter IV. \\ THE DEMAND FOR HIGH-SCHOOL DORMITORIES AND THEIR EDUCATIONAL VALUE.}

The following conclusions and suggestions relative to dormitories in connection with public high schools are a result of the investigation:

Feasibility of dormitories with high schools.-Shall high schools build and equip dormitories? Is there a demand for such a course? This investigation warrants the assertion that, with those agricultural high schools which operate farms in connection with the schools, dormitories are a necessity. The care of crops, live stock, and the details of household management demand that students reside on the farm. Further, if high-school advantages are to be provided for students in localities where transportation is impossible because of long distances and where geographical conditions will not permit consolidation, dormitories are again a necessity.

A comparison of the total enrollment in the schools studied with the number coming from rural districts shows to what extent these schools are serving the rural communities. Seventeen schools reported on this item. The percentage of rural students varies from a minimum of 40 per cent to a maxinum of 94 per cent. The median is 72 per cent. These percentages in themselves justify the statement that these high schools are really serving the rural communities. Not all of these rural children live in the dormitories. Those liring near enough drive back and forth daily. Others board and room in private homes; some rent rooms and cook their own meals; and still others live with a part of their own families, who move into town for the school season. Reports were received from 24 schools as to the actual number of students living in the dormitories. The percentage of the entire enrollment ranges from 10 to 94. The median is 41 . This would indicate that the dormitories are serving a real need. The opinion was generally expressed in the schools visited in sparsely settled regions that dormitories had very materially increased the rural attendance.

Principal D. Lange, of the George Weitbrecht Mechanic Arts High School, St. Paul, Minn., believes that the public high schools in the cities of the country are facing the somewhat novel step of providing and equipping dormitories. His reasons for this opinion are expressed in an article in the September, 1920, number of the School Review. Excerpts from the article are quoted below:

In every large high school which has an enrollment of 1,000 or more pupils, there are a number of boys and girls who for various reasons can not live at home under the control of their parents or near relatives. Every high-school principal knows of good boys and girls whose mothers are not living and whose fathers can not give them proper attention. The result is that such pupils are generally poor students; they contract irregular, if not vicious, habits, and frequently have to be placed in private schools when the father would much prefer to have them attend a public school in his home town.

Then there are likely to be, especially in the western and central western cities, a number of pupils, both boys and girls, who come to the city from the 
country districts, sometimes hundreds of miles away. In some cases these pupils live . with relatives who generally have little or no control over them. I have in mind one case of that kind. A boy about 17 years old, whose parents lived on a farm in one of the neighboring counties, had to work. He associated with vicious companions and came home at all hours of the night. My warnings to the boy had no effect. One night he came home under the influence of liquor. The result was that I had to write his parents to come and take the boy out of school and take him home.

Another boy who came to this school from South Dakota paid his own way by working for a telephone company at night. He occupied a room in a rooming house with a man. The man slept in the room while the boy was at school, and the boy slept while his roommate was at work.

In another case a teacher came to me and said: "One of my boys has no place to sleep to-night. He has been living with his old grandmother, but she has grown so feeble that she will be taken to the hospital to-day, and the boy has no place to go for the night." This boy was an orphan who paid his own way by carrying papers. I went with the boy personally to the Y. M. C. A. and secured a room for him, where he is very comfortable and has been living now for about two years. I think, however, that even the Y. M. C. A. or Y. W. C. A. can not give to pupils of high school age the kind of attention which they ought to have. The solution would be high-school dormitories.

Mr. Lange's opinion was borne out in one of the county high schools visited in Montana. The principal said that he could fill the dormitories with children living right in the town. He said that parents had offered to pay more than $\$ 25$ per month for the privilege of having their children live in dormitories. The reasons given for the request were: "Unable to provide a home," "Want to go to California for the winter," "Can't manage the children at home." Anyone who has had experience as a high-school teacher can relate experiences similar to those cited by Mr. Lange.

Instances where the mother is dead and the father unable to provide a home are familiar to all. Whether it is advisable to erect dormitories as reformatories is debatable. The report of the Carbon County High School in Utah shows how this school protects itself against the admission of students whose personal history is questionable by investigating each applicant's case before a decision is made relative to dormitory residence. The other extreme was found in one of the county agricultural high schools in Mississippi. Here the incorrigibles were welcome, on the theory that it is worth while to " save the lost 'sheep."

The State department of Mississippi is authority for the opinion that their county agricultural schools are among the best high schools of the State. Many rural parents select these schools in preference to town high schools, which are nearer, because of dormitory supervision. In North Carolina the dormitories are serving a real need in providing homes for children who, because of long distances, must be away from home in order to have high-school advantages. There probably always will be sections in the United States where consolidation is impossible. In such sections of the country it is impossible to provide a high school within walking or dfiving reach of every child. Replies as to the practicability of consolidation for the purpose of eliminating the need of dormitories in these sparsely settled regions indicate that, because of the geographical conditions, long distances, and lack of teachers, consolidation is out of the question. The opinion is expressed that the county high schools might become senior high schools wherever there are enough small centers that could be developed into junior high schools.

Some problems in dormitory management.-The problems of dormitory management are as old as dormitories themselves and are as complex as in the days when Tom Brown went to Rugby. One of the first problems is concerned with what may be known as the commissary department. The buying, storing, and handling of food supplies determines to a large degree the living expenses. 
In the schools studied the buying of the food usually devolved upon the school principal or the matron. There were four schools where one person was designated as commissary matron and was given full charge of the buying, storing, and preparation of food. In the Carbon County High School in Utah this woman was a practical housekeeper, and in addition to the buying had general oversight of the cooking. Much preserving and canning of food stuffs was done under her direction. Most of the schools bought supplies in wholesale lots and in large quantities. However, there were a few where this could not be done because of a lack of storage facilities. One matron in Montana, who bought from the local stores, and whose rate of board was unusually low, said that she did the marketing herself instead of relying upon the telephone orders. Further, she bought meat, eggs, and vegetables in large quantities from ranchers whose children lived in the dormitories. Buying from patrons of the school was quite common. The farmers were given market prices for their products.

As a rule, the dormitories visited, with the exception of those located on farms, were unable to buy in large quantities because of a lack of storage room and refrigerator space. Even the schools in connection with farms were usually handicapped when it came to cold storage facilities. All this has its bearing upon buying and the control of waste and these in turn are vital factors in keeping down the price of board.

One or more meals were eaten in most of the dormitories visited. It is unjust to draw a conclusion of the culinary department of any single school from one or two meals. What is said is based on 26 menus representative of 15 different schools. An examination of the 26 menus shows that in 7 instances the menus did not recognize the principle of a "balanced ration." On the whole there was a noticeable lack of milk, meat, and vegetables.

There was very little coordination between the home economics department and the culinary departments of the dormitories. Generally the home economics teacher's cooperation was sought in planning the menus. But this was about all. Seemingly the lessons in domestic science had but little relation to the practical problems presented in the dormitories. In most dormitories the preparation of the meals was in the hands of hired cooks. The students served the meals. In the schools that required an hour a day of manual work this work was rotated among the students. In the other schools it was in the hands of a few who received pay for their services.

Specialists in home economics are of the opinion that the culinary departments of dormitories in connection with public high schools can be linked in a very vital manner with the department of home economics. There is no reason why a certain group of girłs should not be responsible for the preparation of the breakfast cereal for a week, then in turn a vegetable for luncheon or the meat for dinner, and so on until the items on the menus have been exhausted. At the same time another group might be responsible for other items on the menus. In this way practically a large part of the cooking could be actually done by the students. So far no high-school dormitory has reported that such a thing has been tried. Hampton Normal and Agricultural Institute (colored), Hampton, Va., works out just such a plan with its students.

The advantages and disadvantages of part-time students help versus full-time student help was one of the topics discussed at the dormitory-management section of the Montana State Teachers' Association last October. The consensus of opinion, in the schools visited, was that full-time help was more satisfactory than part-time help. Of course, this is to be expected when viewed from the standpoint of the manager. However, from the viewpoint of the child's education, part-time help is to be advised. A student who peels potatoes throughout 
the entire year has a monotonous task. It would be a relief as well as educative to the student to wash dishes for a time or to wait on tables or to make biscuits.

The bookkeeping involved in the management of a dormitory is an item of no small significance. In fact, it becomes very complicated in schools where a large percentage of the students put in a stated amount of time each day in dormitory service and when some of these work overtime for pay. Then, in addition, there are all the items for the purchase of supplies and for the individual board bills. In some instances the principal of the school performed these duties, and in others the matron. Only one school was visited where a secretary was employed for this work. This should be the case in all of the schools. It cripples the efficiency of a supervisor to be burdened with these details.

The biggest and most vital problem in dormitory management is in the choice of matron. All the factors just discussed are more or less dependent upon this. "As is the matron so is the dormitory" is as axiomatic as the adage "As is the teacher so is the school." Every type of matron was found in the schools visited. The extremes were represented by an illiterate woman with a reputation as a good camp cook and a cultured woman who had taken a course in institutional management at Columbia University. In some of the dormitories so many outside duties were placed upon the matron that she had little time and energy to devote to her gwn high office. In a few dormitories the matron has general supervision over the boys' as well as the girls' dormitories. This is true in the county high schools at Price, Utah, and Lewistown, Mont.

It was generally conceded that a woman's presence in the boys' dormitory was as essential to the boys' well-being as to the girls. For that reason it was argued that the preceptor of the boys' building should be a married man. But here again the problem is difficult. The presence of a family of children in the dormitory is detrimental both to the family life of the children and to the dormitory regulations. On the other hand, a young wife who is but little older than the dormitory boys is rarely qualified to hold a responsible supervisory position in a boys' dormitory. Just the type of man and wife needed to handle the situation in a boys dormitory is difficult to find. Most of the preceptors in the boys' dormitories were young men with no experience or training in institutional management. On the whole, the boys' dormitories were not as well managed as were those for the girls.

The personality of a model matron presents a rare combination of qualities. First of all she should be a woman of education and refinement. Further, she should be a good organizer, she should understand dietetics and sanitation, and should be able to command the confidence and respect of young people. Supt. A. M. Cromwell, of Winnett, Mont., says, "She should be a teacher, a cook, a nurse, a mother, a housekeeper, a model, and a very clever organizer." ${ }^{3}$

Social phases of the problem.-A dormitory is or should be more than a place to eat and sleep. It is for the time being a home for the boys and girls who have left their own homes in order to have the advantages of a high-school education. As a home its educational program should be in conformity with the highest conceptions of home management and family life. The rules and regulations of the dormitory are as much a part of the educational program as are the curricula followed in the school building. Any school board that fails to see the dormitory as associated with the educational program of the school fails in its conception of what dormitory life means.

In any well-ordered home each individual feels a personal interest in the wellbeing and upkeep of the institution. In order that this personal interest may be attained it is necessary for the individual to assume some resporsibility in

1 Cromwell, A. M. The Dormitory Dilate, Intermountain Educator, June, 1920. 
the management of the home. Under normal conditions when the high-school student reaches home in the evening there are certain duties that he or she is responsible for. Perhaps the girl must assist in the preparation of the evening meal, and the boy (if he lives on a farm, and the children concerned in this study are farm boys and girls) do the evening chores. If the dormitory is to be a substitute for the home, it is necessary that the students living in the dormitory assume a responsibility similar to that which is assumed at home. In visiting. the schools it was customary to spend the hours between the closing of school and the evening meal about the girls' dormitories. In the schools where dormitory duties were required by all students there was far less restlessness than in the schools where this was not the case. In the latter instances the girls were uneasy. Apparently they did not know what to do with the time between 4 and 6. They were constantly asking permission to go down town. The reasons for their requests were varied. Those heard most often were, "Want to go to the movie;" "My mother is in town and I want to see her;" "Got to do some shopping for the folks."

If dormitory rules are to be educational, they should function in the life of the students. The prime object in requiring that rooms be in order is to establish in the life of the student habits of orderliness and neatness. In most of the dormitories visited there was a certain hour when the rooms were inspected by a supervising officer. A visit to the rooms, either before or after inspection, showed in many instances the opposite of arderliness and neatness. In fact, many of the boys' dormitories were virtually filthy. Still worse, there were evidences of wanton destruction of property.

A dormitory offers abundant opportunity for inculcating correct social usages, respect for the rights of others, and proper ethical standards. The ground is fertile, but the accomplishment of the task is difficult. Young people from all sorts of homes and conditions are brought together as one family group. The education one receives from his dormitory companions often registers deeper than that received from the teachers in the classrooms. The herding of young people together in a dormitory may easily result in deterioration of character and even gross immorality. Every facility must be utilized to develop a healthy and normal family life.

In this connection the dining hall is cited as one of the most effective agencies for developing good manners. In most of the schools boys and girls were grouped together at the tables. The general opinion seemed to be that this produced better results than segregation. All sorts of conditions were found, from the school that made no attempt to use the meal time as an agency for social betterment to one where every detail concerning proper table etiquette was carefully considered. There were instances where the boys and girls rushed from the schoolhouse to the dining room without even stopping to wash their hands. There was one case where the scene reminded one of a threshing crew in a mad rush to get first place at the table. However, this was not the general rule. Usually at a sound of the gong the students marched in an orderly fashion to the dining hall. Grace was said at the meals in all the schools of the South that were visited and at the Carbon County High School in Utah. Mention is made in the appendix of how student cooperation is sought at Lewistown, Mont., in bringing about proper table manners as well as other right ethical standards.

In the schools where the boarding students were organized with municipal courts, student councils, and ethical clubs, dormitory life was recognized as a very real laboratory for the inculcation of those principles which make for good citizenship in a democratic government. One felt that the participation of the students in the government of the dormitories reacted in a healthful 
manner to the general welfare of all. In one of the schools visited the matron said, "One would hardly recognize some of these girls after they have been with us for a few months as the same girls who came to us in September, so changed have become their manners, their ideals, and even their dress."

Conctusions and suggestions.-In view of the discussion of this chapter, as well as the findings in the chapters on "Buildings" and "Management," the following conclusions and suggestions are drawn relative to dormitories with public high schools :

\section{THE NEED FOR HIGH-SCHOOL DORMITORIES.}

In agricultural high schools where a demonstration farm is maintained by the school, dormitories are a necessity. In localities where geographic conditions prohibit consolidation, the dormitory is the best means of providing for the housing of students who live at remote distances.

\section{BUILDINGS AND THEIR EQUIPMENT.}

(a) It is more satisfactory for boys and girls to be housed in separate buildings.

(b) High-school dormitories should be as well equipped and as modern as the most up-to-date college and normal school dormitories.

(c) Every school maintaining dormitories should either include a steam laundry as a part of the plant or should provide laundries in the basements of both boys' and girls' dormitories. These provisions are necessary because it is impossible for all the children to spend the week ends at home. In schools located on farms it is undesirable to permit a large number of the students to be away over the week end.

(d) Hospital wards should be provided in every dormitory when there is not a separate hospital building.

(e) When the attendance is large it is more satisfactory to have a building especially designed to house the dining hall, kitchen, and storerooms.

\section{MANAGEMENT.}

(a) The superintendent or principal of the school should have general management of the dormitories.

(b) A secretary should be employed to take charge of the bookkeeping connected with the dormitories.

(c) One person should be given sole charge of the marketing; it is best not to burden the matron or principal with this duty.

(d) There should be close coordination between the home economics department of the high school and the culinary department of the dormitories.

(e) It is desirable that all students living in the dorm:tories should assume some responsibility in the upkeep of the institution.

( $f$ ) A good general education, the right personality, and training in institutional management should be expected of matrons and others assuming supervisory duties in dormitories.

\section{SOCIAL SERVICE.}

(a) The life of the dormitory should be in keeping with the highest conception of home and family: life.

(b) The object of dormitory rules should be the inculcation of right habits within the individual and right relationships with others.

(c) Student cooperation in the affairs of the dormitory should be sought. 



\section{APPENDIX.}

\section{REPORTS FROM 10 SCHOOLS.}

The appendix contains reports from dormitories in connection with 10 high schools throughout the United States. These are representative of the following types of high schools maintaining dormitories: (1) Congressional district and county high schools located on farms; (2) farm-life schools; (3) county training schools for colored teachers; (4) county and district high schools.

\section{CONGRESSIONAL DISTRICT AND COUNTY AGRICULTURAL HIGH SCHOOLS.}

The congressional district high schools of Georgia and the county high schools of Mississippi are essentially boarding schools. The object in establishing these schools is to prepare the rural population for happy and useful lives on the farms. Dormitories have been parts of the schools from the beginning, because of the conviction that agricultural and domestic science can best be studied when pupils live on the premises. These schools are on farms, and the students study agriculture and home science in the most direct way-by practicing it under actual farm conditions.

The following reports made from personal observations of the seventh congressional district agricultural school in Georgia and the Hinds County high school in Mississippi give in detail some of the situations in schools of this type.

Serenth District Agricultural School, Powder Springs, Ga.

[Visited November 16, 1920.]

This school is located $2 \frac{1}{2}$ miles from Powder Springs, Ga. The school has 240 acres of land well fitted for agricultural purposes. The academic building, the two dormitories, and the dining hall are built of brick. They are modern, with the exception of heat. Corner grates in each room, burning wood, supply the heat. Both dormitories were erected about six years ago, at a cost of $\$ 15,000$ each. In each dormitory 125 students can be accommodated. All the students' rooms are provided with furniture and mattresses. There is in the girls' dormitory an isolated room containing four hospital beds and all modern hospital equipment. A nurse's room adjoins this.

Table board is furnished at cost. The farm supplies much of the meat, the milk and butter, the vegetables, and the grain. In 1920 table board averaged $\$ 14$ per month. The dining hall could accommodate 400 persons. A commissary matron has charge of the kitchen.

A student without money can earn a large portion of his expenses here, as he can in the other congressional district high schools in Georgia. Nothing is given to any student. A student who can not pay anything must work 100 hours per month. This will pay his way as well as bring him money at the end of the month. One is advised not to come expecting to work off all expenses unless arrangements have been made for it before entering school. About 10 places with the privilege of working the entire way were given this year. 
The members of the faculty live in the dormitories with the students, and are responsible for good conduct. Every Friday night a student court is held where all cases of discipline that are not an infringement of school regulations are tried. Members of the faculty are present at these hearings.

The total enrollment of the school is 245 , of whom 190 live in the dormitories. The remainder come from Powder Springs and vicinity. The dormitories are crowded. New dormitories are needed, with a capacity of 400 students. When the school started 10 years ago there were 75 pupils. The school does not advertise. This year 100 students were turned away for want of room.

\section{Hinds County Agricultural School, Raymond, Miss.}

[Visited November 5, 1920.]

The school farm consists of 154 acres of choice farm land, and is well stocked with modern farm implements. Such farm crops as are not utilized on the farm are put upon the market. Vegetable gardens, a dairy herd, and DurocJersey hogs provide food for the boarding department. The school building, the principal's cottage, and the boys' and girls' dormitories face a broad driveway and a spacious lawn.

The boys' and girls' dormitories were built in 1917, the former at a cost of $\$ 17,400$ and the latter at a cost of $\$ 19,000$. Both are modern throughout. Both dormitories will house 144 students- 84 boys and 60 girls. Ninety students were housed in the two dormitories when the school was visited- -40 boys and 50 girls. All students' rooms are furnished with double-decked beds, mattresses, chairs, and a table. Students are asked to bring the following articles from home: Bed covering, sheets, pillows and cases, towels, and napkins.

The dining room is in the basement of the girls' dormitory. Teachers without homes take their meals at this dining room along with the dormitory students. Because much of the food is produced on the farm and because much of the labor is done by the students, the cost of board is kept at $\$ 14$ per month. This includes the food that must be bought, the salary of the cook and of the matron, and water, lights, and electricity. A professional Negro cook is employed. He is paid $\$ 85$ per month, is furnished a four-room cottage, and is given the privilege of buying groceries at wholesale. The matron is paid $\$ 75$ per month, is furnished a parlor and bedroom and table board. She has general oversight over the girls' dormitory and prepares the menus.

Three men teachers live in the boys' dormitory and share the responsibility of discipline. Nine women teachers live in the girls' dormitory and assist the matron with the management and discipline.

Every student must perform a certain amount of labor each day either on the farm or in the buildings. Aside from this required manual labor, students receive pay for various kinds of work. Eight girls receive $\$ 6$ per month for washing dishes and sweeping and dusting; two girls receive $\$ 6$ per month for two and one-half hours' service per day in the library. Boys are paid from 20 cents per hour to $\$ 10$ per month for labor upon the farm. One boy receives $\$ 6$ per month for delivering the mail.

All students are encouraged to take part in wholesome athletics and amusements. Football, basket ball, tennis, track work, and croquet are under the direction of competent supervisors. Only such students as do satisfactory work are permitted to play on the school teams. All social activities, such as picnics, parties and " high Y's" are chaperoned by members of the faculty.

During the present year the number of boarding students has decreased somewhat. This is due to the "hard times," to the charging of tuition from 
students outside the county, and to the growth of consolidated schools. It would seem that the time is not far distant when this school would best function as a senior high school. By far the largest enrollment is now found in the junior and senior years. The total enrollment of the school is 127 , and 90 of this number, 71 per cent, are dormitory students. This would indicate that the school is readily serving the entire county and not simply Raymond and its vicinity.

\section{FARM-LIFE SCHOOLS.}

The statutes of North Carolina provide for the establishment of " county farm-life schools." The board of trustees is comprised of practical farmersone member from each township in the county who is appointed by the county board of education. The object of these schools is to train boys and girls for farm life and home making. These schools must not be located in any city or town of more than 1,000 inhabitants, nor within 2 miles of the corporate limits of a town of more than 5,000 inhabitants. The law provides for a farm of not less than 50 acres in connection with these schools, for the erection of farm buildings, for a school building, and for dormitory buildings with suitable accommodations for not fewer than 25 boys and 25 girls. Provision is made for the maintenance of high-school departments and for farm life extension work in the county under the direction of the State department of education, the North Carolina State College of Agriculture and Engineering, and the United States Department of Agriculture.

It has already been stated that the State department of education reports that these schools have never fully realized the intent of the law makers as real farm life schools. Yet in localities where consolidation is either unfavorable or impracticable the dormitory feature of the schools has filled a real need in providing housing for country boys and girls who must leave home in order to secure a high-school education. A report of one of these high schools follows :

Cary Public High School and E. L. Middleton Farm-Life School, Cary, N. C.

[Visited November 19, 1920.]

This high school and farm-life school is an outgrowth of the old Cary High School which had its origin in the last century and was owned and controlled by a stock company. The old school was one of the leading boarding schools of its time and drew patronage from a large section of the State. However, the new school with its modern school building and dormitories has lost none of the prestige of the old.

Both the dormitories are built of brick and have modern equipment. The boys' building was erected in 1919 at a cost of $\$ 26,000$ and the girls' building in 1916 at a cost of $\$ 11,000$. Each dormitory has a capacity for 60 students. At present 75 boys and 85 girls are crowded into the two dormitories. Students' rooms are furnished with furniture and mattresses. Other articles must be supplied by the occupants of the rooms. Additions should be built to each dormitory. The opinion was expressed by the principal that if the housing facilities were increased the number of boarding students would reach 250 .

The dining room is in the basement of the school building. It has a seating capacity for 225 persons. The amount paid for board covers the cost of food, its preparation, and its service. In 1920 the average was $\$ 14$ per month. In 1921 it has averaged $\$ 15$ per month up to the present time. The Negro cooks are paid $\$ 5$ a week each and their board. The commissary matron receives 8 
per cent of the gross receipts. She does all the buying and plans the meals in cooperation with the supervisor of home economics. Special attention is paid to table etiquette. A long list of rules explaining the elements that constitute good table manners is provided for each student.

The adviser for boys, who is one of the men teachers of the faculty, lives in the boys' dormitory and with three assistants supervises the boys and enforces the dormitory rules. This adviser has an attractive office in the building. He tries to make this office and his own room a model of good housekeeping. The adviser for girls is known as the lady principal. She lives in the girls' dormitory and is responsible for the conduct of the girls.

Student cooperation is sought in the government of the school. There are four organized groups among the student body-one of the dormitory boys, one of the dormitory girls, one of the local boys, and one of the local girls. Each group has a student council. This council elects a proctor and assistants. A general council is made up of representatives from each group. This general council elects a president, a vice president, a secretary, and an adviser from the faculty. Matters pertaining to discipline and the general welfare of the school are discussed at these meetings.

The visitor heard at the chapel hour reports from these student groups. These reports covered dormitory inspection and health score cards. At the close of the period a student representative from the council arose and asked all dormitory boys to remain immediately after chapel. Later it was learned that the question under consideration was what to do with a group of boys who hazed a new student the night before.

The question was asked whether it would be possible to locate enough high schools in the area served by the Cary Farm-Life School to eliminate the need for dormitories. The answer was that it was possible but not probable because of lack of funds and because public opinion was not yet sufficiently awakened to the need for consolidated schools. The opinion was expressed that the small centers in the surrounding country might well develop into junior high schools and become feeders to a senior high school at Cary.

\section{COUNTY TRAINING SCHOOLS FOR COLORED TEACHERS.}

The 1920 directory issued by the State department of education of North Carolina lists 21 county training schools for colored teachers. These schools include both elementary and high-school departments. The chief purpose of the high-school departments in these schools is to train colored teachers for rural schools. The Berry O'Kelly Training School in Wake County is one of the best of these schools.

\section{Berry O'Kelly Training School (Colored), Wake County, N. C.}

[Visited November 19, 1920.]

This school is named in honor of a prominent colored citizen who has contributed generously toward the support of the school.

Several small one-story frame buildings have been joined together and remodeled for a girls' dormitory. Ten girls are cared for in this building. A frame building is donated as a rooming house for the boys. Twenty-three boys are housed in the building. No charge is made for the rooms. All furnishings, with the exception of dressing for the beds and towels, are furnished by the school board.

The kitchen and dining room is in the girl's dormitory. Every student is required to work one hour each day. This hour of work includes janitor 
services in both dormitories and the school building, the care of the grounds, and cooking and serving of meals. By this arrangement practically all of the labor is performed by the students. The amount charged for meals is intended to cover the cost of food and its preparation. In 1919 it was placed at $\$ 8$ per month, but at the end of the year found a deficit of $\$ 190$. In 1920 the price was set at $\$ 12$ per month. This is intended to cover the cost of food, its preparation, lights, a matron's salary of $\$ 75$ per month, and the deficit of last year.

The matron is the domestic-science teacher. She and seven of the women teachers live at the girls' dormitory and have supervision of the girls. The principal of the school and the agriculture teacher have similar oversight of the boys. These men make nightly visits to the boys' rooming house. Cooperation is sought of the students in the matter of discipline by means of a student committee. A literary society meets every Friday evening. This is strictly a school affair. The Y. M. C. A. and Y. W. C. A. hold regular meetings on Sunday afternoons. The athletic activities find expression in baseball, basket ball, and tennis.

In 1921 was the first time that the school had a high-school department. At present the high-school enrollment is only eight. With new and larger dormitory accommodations the enrollment of the school could be greatly increased.

\section{COUNTY AND DISTRICT HIGH SCHOOLS.}

A provision for county high. schools is common in States that contain sparsely settled areas. In many instances the county high school is the only high school in the county. If these county high schools are to serve all the people who really support them, it is necessary to make provisions for the care of those children who live at remote distances. It was to meet this need that dormitories came into existence in county high schools. What is said of county high schools may well be said of large district high schools in sparsely settled regions. The growth has been most rapid in the Western States. However, the need for dormitories is as acute in connection with county and district high schools located in the mountains of West Virginia as with those found on the plains of eastern Colorado. The reports that follow are representative of county and district high schools in Montana, Nebraska, Nevada, Utah, and Virginia.

\section{Fergus County High School, Lewistown, Mont.}

[Visited October 5 and $6,1920$.

Fergus County, situated in the center of the State of Montana, has an area approximately equal to the combined areas of the States of Connecticut and Rhode Island. The surface consists, for the most part, of hills, mountains, and extensive benches. The county high school is located at Lewistown, a thriving town of about 8,000 population. In addition to the county high school, there are 13 district high schools, ranging from two to four years of accreditment, scattered throughout the county. If all the rural children eligible to enter high school, and living in districts adjoining these high schools, should drive back and forth to the 14 schools, there would still be children living in more than 100 districts beyond the driving distance of any high school.

The county school board of Fergus County encourages the development of these district high schools. It belleves that whenever high schools are within driving distance of country children it is better for them to attend the district 
high schools and be at home. The county high school especially encourages the attendance of students who are so far away that they must leave home in order to attend high school. In reality, however, its broad curriculum does attract students within proximity of the district high schools.

The county school board further believes that the Fergus County High School should not only serve all the children of the county but all the adults as well. Accordingly, it offers industrial and commercial courses as well as classical and scientific courses. Short winter courses are offered in agriculture, gas engines, automobiles, and home economics. Farmers' week is a special feature of the school. During this week the students close their books and go to their homes, leaving the buildings and the faculty for the use and instruction of their fathers and mothers, as well as of all the farmers and farmers' wives in the county.

In this campaign to make the county high school serve the entire county it soon became evident that a place must be provided for students to live when they come to Lewistown. It was this thought that inspired the business men of Lewistown in 1917 to build a girls' dormitory at a cost of $\$ 23,000$. In 1920 another unit, costing $\$ 40,000$, was added to this building. For the use of this dormitory the county pays annually 7 per cent interest and 5 per cent for liquidation on the entire investment. Each year the amount liquidated is deducted from the principal.

The building is modern throughout. It can accommodate 108 girls. The students' rooms and parlors are attractively furnished. In fact, the building and its furnishings would do credit to any normal school or college dormitory. Students are requested to bring dressing for their beds and to bring their own towels and napkins. A dining room in the basement accommodates both dormitory girls and boys and the teachers without homes. This dining room can serve 200. There is also a laundry in the basement for the use of the girls that find it necessary to do their own laundry work.

The school board felt that the county girls should first be cared for, and then something should be done for the boys; so a year or so after the business men of Lewistown made a girls' dormitory possible the school board rented a large dwelling house and transformed it into a boys' dormitory. This building accommodates 30 boys. In Lewistown, as well as in other Montana high schools visited, it was found that a much larger number of country girls attended the high school than did boys. The school authorities realize that the next step is to provide a dormitory for the boys.

One felt in visiting the high school at Lewistown that unusual care and thought was given to out-of-town students. In fact, Principal Cummings believes that the faculty and school board should assume responsibility for the welfare and progress of these students, whether they live at the dormitories or in private homes. The matron of the girls' dormitory has general supervision of both dormitories. She directs all social activities of dormitory students, prepares the menus, buys supplies, and performs the office of bookkeeper. An assistant is provided for her. Two men teachers live at the boys' dormitory and assume responsibility for the enforcement of the rules. There is also a dean of women, who has general oversight of all girls living outside the dormitories. Thirty-five girls exchanged services for room and board in private families. Last year this dean of women found 110 jobs for 80 different girls. Approximately $\$ 12,000$ was earned during the past year by girls and boys who exchanged services for board and room or who worked part time outside of school hours. When a girl leaves a home she is expected to give a week's notice to the woman in charge of the home. The same notice is expected of women who employ 
the girls. Dormitory rules relative to study, retirement, and going out at night are applied to students in private homes. A man on the faculty performs a similar service for boys who live outside the dormitories.

The cost of food, its preparation and serving, is prorated among those taking their meals at the dormitory dining room. In 1919 it averaged $\$ 18.50$.per month. During the month of September in 1920 it was $\$ 20$. A professional cook is employed. She is assisted by a dormitory girl, who receives $\$ 15$ per month for her services. Five girls wash dishes and wait on tables. For these services they receive their board. Special emphasis is placed upon table etiquette. Senior students are seated at each table and assume responsibility for breaches. in table manners. All marks of ill breeding are reported to the matron and these things are discussed informally and impersonally at the dormitory club. The object of this club is to promote high ethical standards among dormitory students.

The enrollment of the Fergus County High School for the school year 1919-20 was 740. Of this number, 374 were from the rural districts.

The High School at Stanford, Mont.

[Visited October 7, 1920.]

The Stanford school district, situated in the wheat-growing district of Great Judith Basin, Mont., is approximately 22 miles long and 18 miles wide. The ranches are large and the district is very sparsely settled. There are five outlying rural schools besides the school in the village of Stanford.

For some years a high school has been maintained in Stanford, but the attendance has been small. In 1917-18 it was 11; in 1918-19 it was 15. In 1919 the superintendent of schools began a vigorous campaign about the middle of August for recruiting students. Everywhere he went he was confronted with the question "Where will the children live?" It was impossible to find places for the children in the private homes of the small town of Stanford, so necessity was the compelling force that moved the school board in the fall of 1919 to rent a vacant hotel building at a cost of $\$ 50$ per month and convert it into a dormitory. That year the high-school enrollment increased to 43 . The next fall it was 72.

This old hotel building is a frame structure 60 feet long and 30 feet wide. It is heated by a furnace and lighted with electricity. There is no plumbing system. The boys occupy the upper floor and the girls the lower floor. Eighteen boys and fourteen girls can be accommodated. In October (1920) when the school was visited 15 boys and 14 girls were rooming in the building. Twentyeight were taking meals at the dormitory, six of whom were teachers. Beds, mattresses, and chairs are provided by the school board.

The matron, who is a long-time resident of the community, performs the duties of cook, purveyor, bookkeeper, general disciplinarian, and adviser. She is assisted in her household duties by two girls who receive board for their services. One dormitory boy cares for the furnace, for which service he receives his board.

The charge for table board is prorated on a cost basis. The matron's salary and heat and light are included with the food item cost. In 1919-20 the cost varied from $\$ 15$ to $\$ 18$ per month per student. In September of 1920 it was $\$ 20$ per month. The teachers pay a flat rate of $\$ 25$ per month.

The dormitory experiment has convinced the authorities at Stanford that the school district should provide dormitories for both boys and girls. Buildings accommodating 50 of each sex would doubtless be filled in a short time. 
Chase County High School, Imperial, NeBr.

[Visited October 21, 1920.]

The county school board of Chase County, Nebr., realized a few years ago that the reason more students from the farms and ranches were not attending the county high school was because there was no place for them to live when they came to Imperial, where the county high school is located. This fact was the compelling motive that actuated the president of the school board to erect, in 1916 , at a cost of $\$ 5,000$, a frame building suitable for a dormitory. The building is 40 feet long and 30 feet wide, with two stories above the basement. It is heated by a furnace, lighted by electricity, and has one bathroom on the second floor.

The first two years of the dormitory experiment the building was filled with students, but this has not been the case during the past two years. Last year the school board faced a deficit of $\$ 250$. The county school board provided for this deficit and gave up the experiment as a school project. At the present time the president of the board has turned the building over to the matron, who conducts the dormitory as a private boarding house. Six students room and board there, and are under the same regulations as the other boarders. A charge of $\$ 8$ per month is made for rooms if one occupies a room alone, and $\$ 12$ per month if two persons occupy a room. Forty cents. is charged for each meal.

The failure to keep the dormitory filled with students is ascribed to the financial depression and to the competition of three other high schools in the county. The total enrollment of the high school is 61 . Of this number, 36 come from outside Imperiai. Twelve of the outsiders look after their own housekeeping arrangements, 12 drive back and forth, and 12 board in private homes.

\section{Euko County High School, Elko, Nev.}

The county high school at Elko, Nev., comprises an academic building, a gymnasium, manual art shops, and a dormitory. The entire plant is valued at $\$ 195,000$. The following paragraphs relating to the dormitory are excerpts from the report of Principal G. C. Jensen for the school years 1917-18 and 1918-19. This report was prepared for the secretary of the board of education:

The dormitory (Hillcrest Hall) is a frame building with a shingle exterior. Its total cost was approximately $\$ 43,000$. The building is a double affair, there being no opening through from the boys' to the girls' side upstairs and the only communication downstairs being through two parlors and the dining room. 'There are 14 bedrooms on the boys' side and 12 on the girls' side. Besides these rooms there is a matron's parlor and kitchenette, two linen closets, a girls' parlor, a boys' parlor, a dining room large enough to seat 100 persons, 7 bathrooms, a laundry, and a large kitchen with its pantries, and quarters for servants. This dormitory, aside from the quarters for the matron and assistant matron and other help, will house from 40 to 45 persons. Special rooms have been provided above the dining room for the teachers.

A financial report for the 18 months of the dormitory's operation follows:

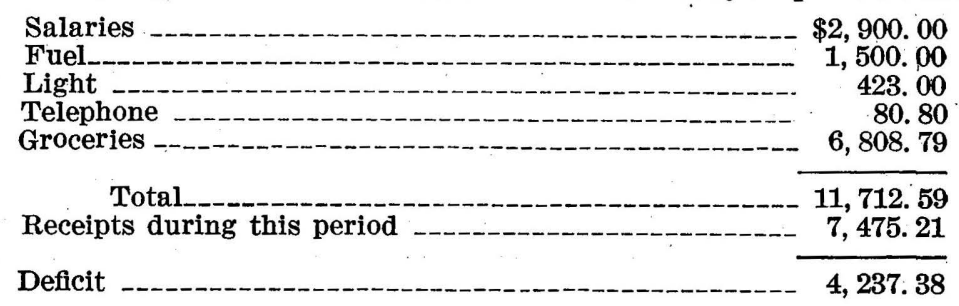




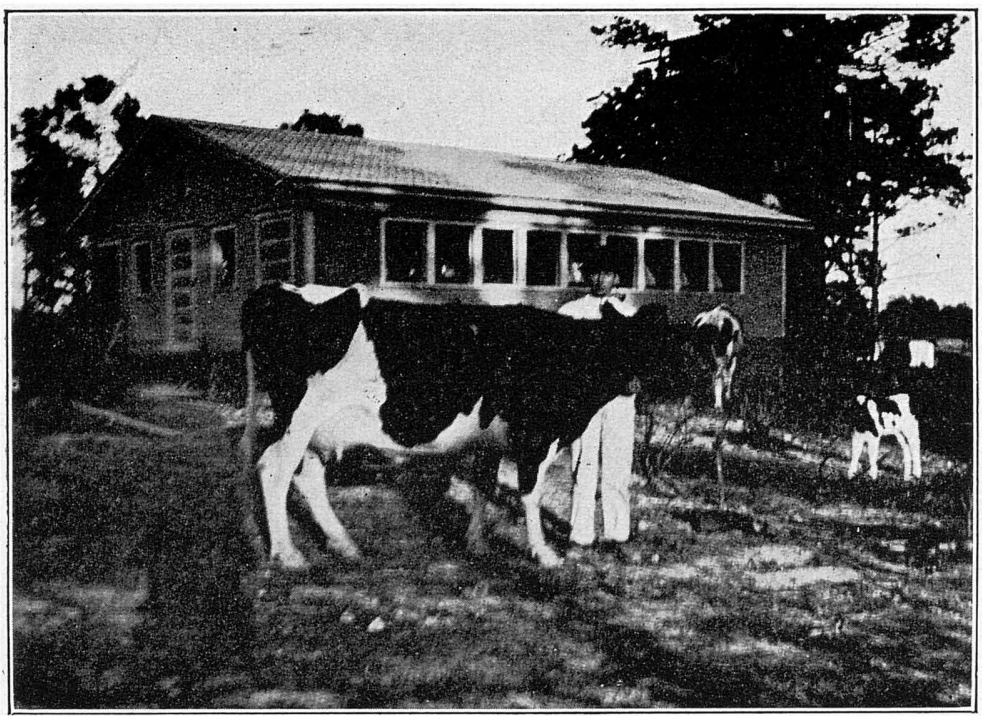

A. SILO, DAIRY BARN, AND REGISTERED HOLSTEIN, SEVENTH DISTRICT AGRICULTURAL HIGH SCHOOL, POWDER SPRINGS, GA.

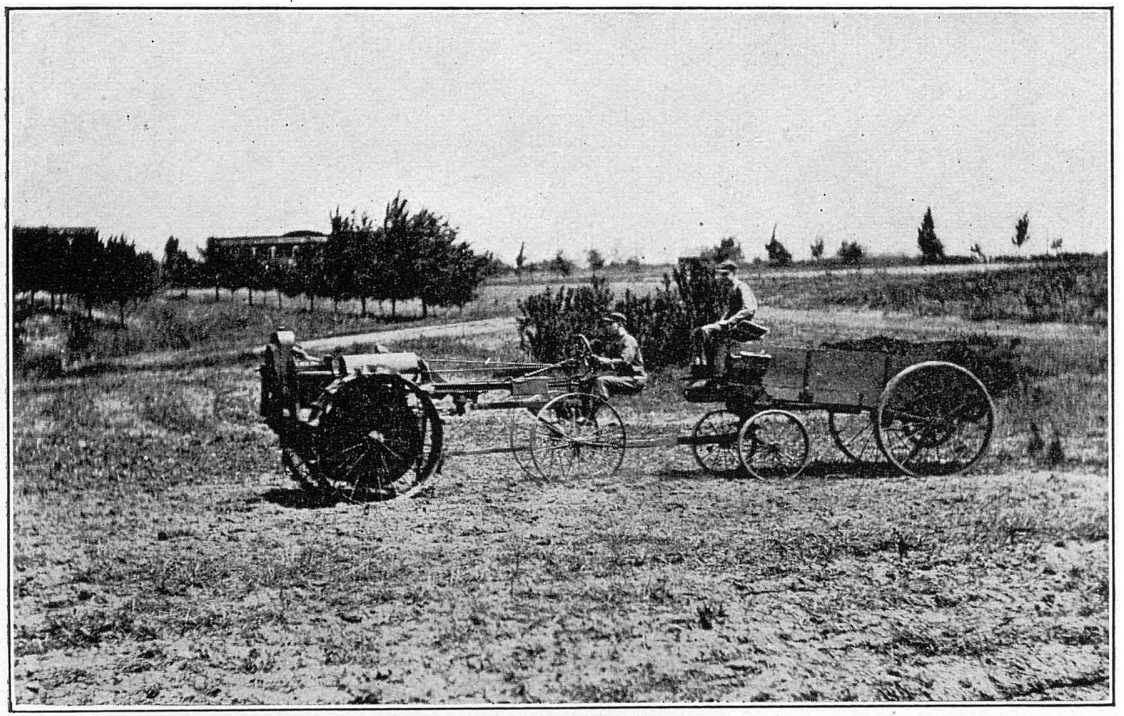

B. BOYS IN FARM WORK, CONGRESSIONAL DISTRICT HIGH SCHOOLS, GEORGIA.

Each boy must put in at least one hour's work a day on the farm. 


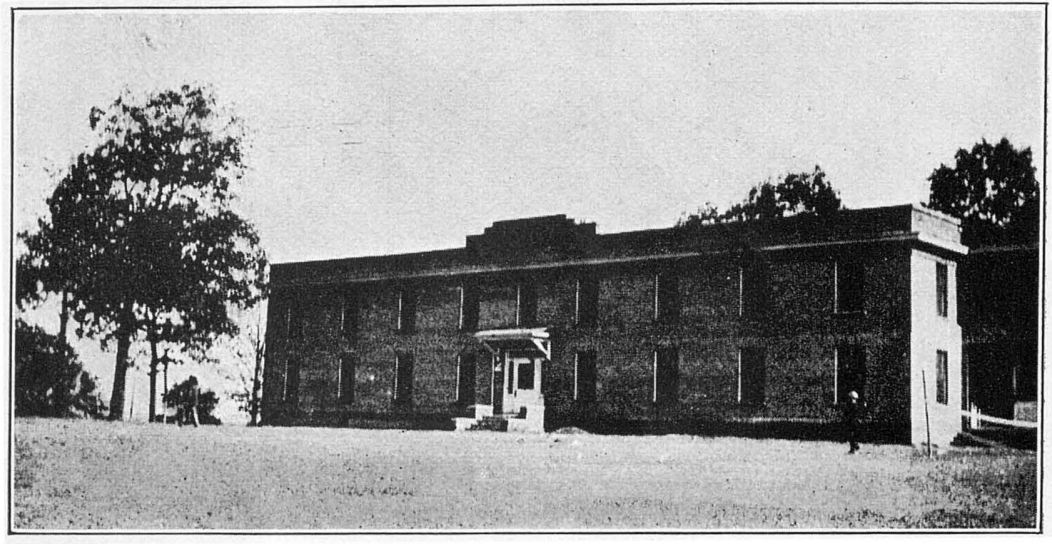

A. BOYS' DORMITORY, FARM LIFE SCHOOL, CARY, N. C.

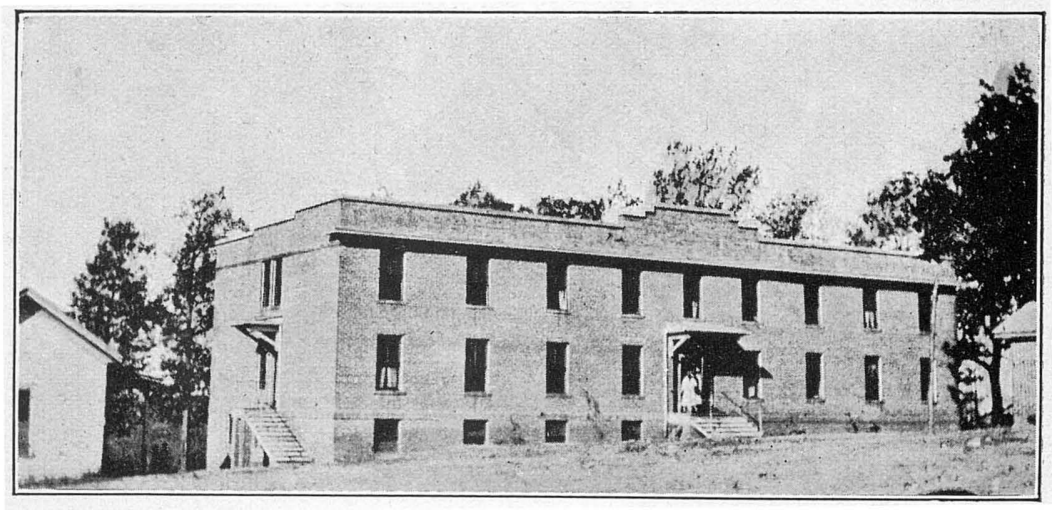

B. GIRLS' DORMITORY, FARM LIFE SCHOOL, CARY, N. C. 


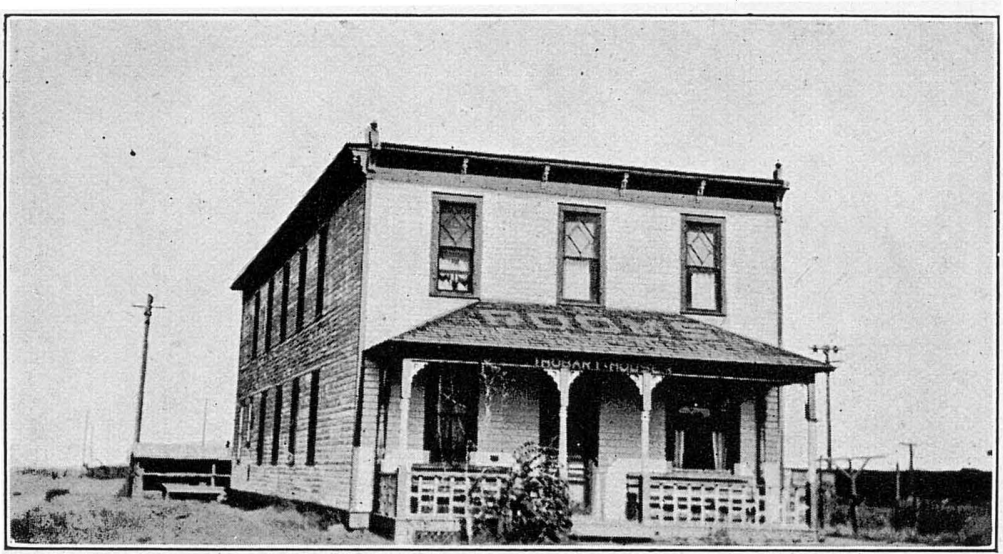

A. OLD ROOMING HOUSE TRANSFORMED INTO A DORMITORY, STANFORD, MONT.

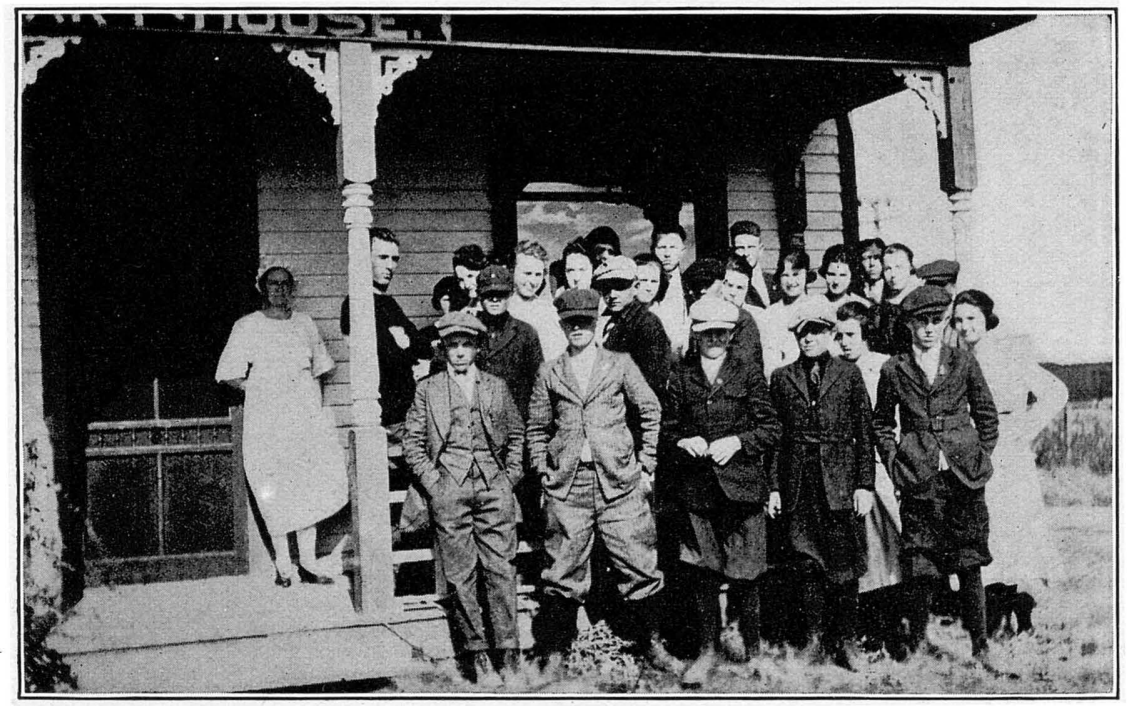

B. DORMITORY STUDENTS, STANFORD, MONT.

"Just after luncheon." 


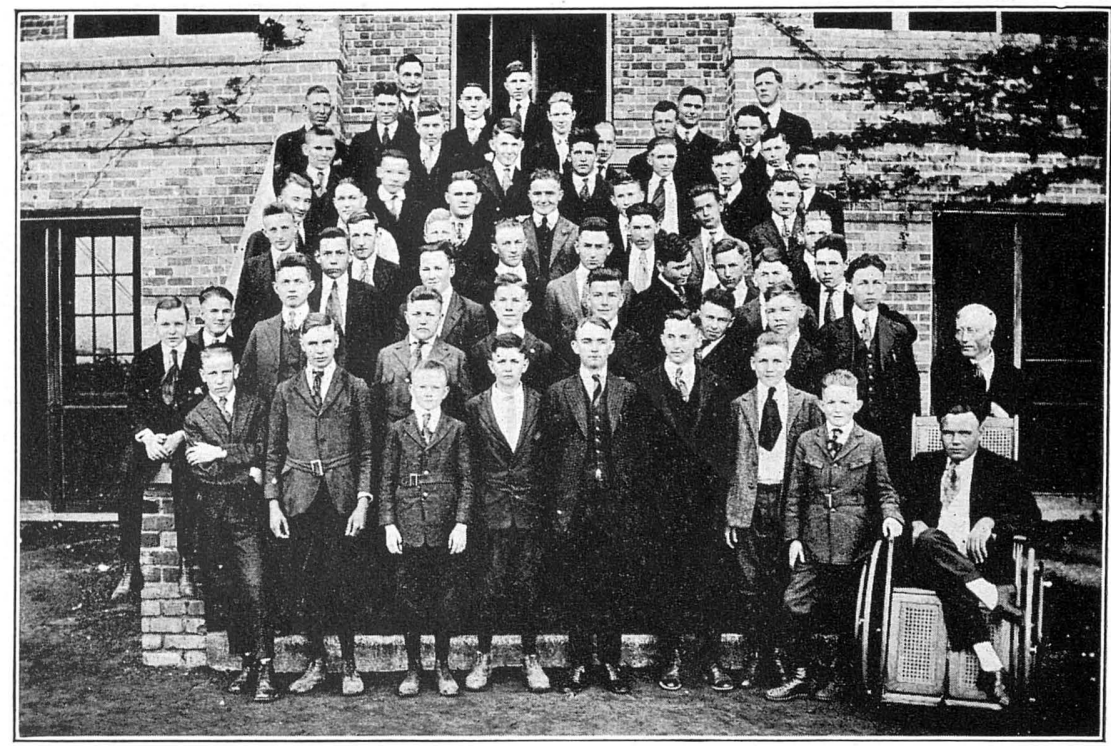

A. DORMITORY BOYS-JONES COUNTY AGRICULTURAL HIGH SCHOOL, ELLISVILLE, MISS.

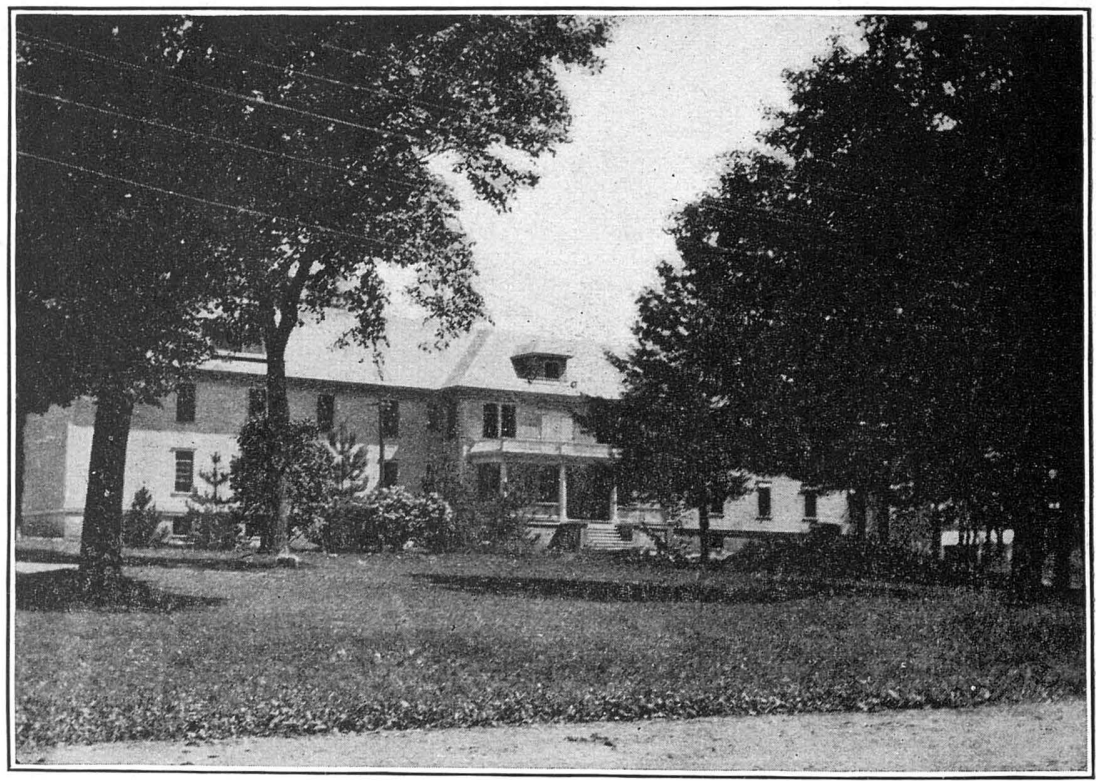

B. DORMITORY, VERMONT STATE SCHOOL OF AGRICULTURE, RANDOLFH CENTER, VT. 
During the spring of 1917 (the first term of its operation) 9 students and 6 faculty members were housed for a period of one month or longer; 6 of these students and 4 of the faculty remained the entire term. During the spring of 1919,37 students who were not rooming at the dormitory were . served lunches there.

During the year 1918-19, 32 students were housed at the dormitory for a period of one month or more, 16 of them for the entire year. Four members of the faculty remained during the year. Fifteen students took their lunches at the dormitory during the bad weather.

Besides the 16 students who remained at the dormitory during the entire year, 8 others entened when school reopened after the epidemic and remained for the balance of the year.

It is noted that the second year shows a decided increase in numbers at the dormitory over the first year. The prospects are that the coming year will see the institution full to overflowing. With the increase in numbers, the deficit should be gradually reduced.

This deficit should not now be considered by the citizens of Elko County as a loss. Last year 36 different students found quarters at the dormitory who in the absence of this hall would have sought quarters elsewhere. This would have meant that a number of these would have been unable to do so, with the result that many would probably. have left the county and State for their training. Two students worked for their board and lodging during the past year. * * * The epidemic had considerable to do with the deficit last year; the income was almost completely cut off, while many of the overhead expenses, such as salaries, went on. The marked rise in prices has had its effect too. Students are housed and boarded at the hall for $\$ 25$ per month. It is felt that it would be impossible to raise this charge, for any increase would seriously affect some students. It seems wisest at present to consider any deficit as part of the cost of educating the youth of Elko County.

The dormitory has now had 18 months of experience. There are many problems that surround an institution such as this-problems the solutions of which are not all evident. Were all of the students who are attending the school living at the hall, the question would be far simpler. * * * The school has an unquestioned duty to make every effort to solve these matters. The hall is now well established, and far more independence can be assumed by the school than when this phase of its life was in the introductory stage. It is the duty of the school to build round this home for boys and girls safeguards which will protect them as well as protect the school itself. Next year the boys and girls living there will come under very strict but beneficial rules. It is proposed, for instance, that girls shall be chaperoned as girls elsewhere are chaperoned; that hours of study shall be observed; that boys as well as girls shall be limited in the time spent socially; and that parents shall assent to these rules before the students are accepted. * * * These specific rules will be sent to the parents and students concerned later on in the summer, after they have been thoroughly formulated. The school solicits the advice and cooperation of all citizens of Elko County in the successful operation of this dormitory experiment.

\section{Carbon County high School, Price, Utah.}

[Visited Oct. 22, 1920.]

The Carbon County High School, at Price, Utah, is the only high school in a county with a school population of 3,823 , scattered throughout 21 communities, most of which are mining camps. Seventy per cent of the population is either foreign born or of foreign parentage.

In 1918 the school board purchased for $\$ 15,500$ the buildings formerly oceupied by the Price Academy; they remodeled and repainted them and fitted them out for high-school students living in the outlying towns of Carbon County who wished to attend the Carbon County High School.

The dormitory campus occupies one-half of a block, and two dormitories and two cottages that supplement the dormitories are upon it. A pigsty with several pigs and a woodpile on the dormitory campus provide their share of chores $95251^{\circ}-22-3$ Lisitisit?

$$
\begin{array}{r}
\text { THA TOOLOGKAL COLLESE } \\
\text { LOWOCK TEXAS }
\end{array}
$$


for the boys. The pigs are kept for the disposition they make of the kitchen garbage. Later they will contribute their portion of food for the family table.

The chief executive is known as the dean of dormitories. She has general supervision over both dormitories. A preceptor, who is one of the men teachers, lives in the boys' dormitory; he supervises and inspects the work, the study hour, and the physical activities of the boys. One of the women teachers assists the dean with the supervision and inspection of the girls' dormitories. One teacher lives in each cottage and is responsible for the supervision of the students living therein. A commissary matron buys the food and with the help of an assistant prepares it for the tables. The dean of dormitories decides upon the menus. Care is taken to see that these menus show a "balanced ration."

The dormitories and the cottages will accommodate 75 students. Fifty-five are already there. Isolated rooms are reserved in each building for cases of sickness. The school board provides all furnishings with the exception of bed linen, blankets, and towels.

The dining room is in the basement of the girls' dormitory. Seventy-five can be served in this hall. The dean of the dormitories and her assistants believe that dining-room etiquette is a very vital factor of dormitory life. Consequently, much stress is laid upon the proper manner of entering and leaving the dining room and the observance of right table manners. A flat rate of $\$ 20$ per month is charged for table board. This rate is intended to cover the price of food, its serving, the salaries of the employees, and fuel and light. Last year there was a deficit of $\$ 529.16$ in the cost of operation. This was due to the increase in the cost of food. The school board made good this loss.

Considerable care is given to an investigation of the scholastic and citizenship standing of the students desiring residence at the dormitories. A student asking to be admitted to the dormitories is required to answer the questions asked on a formal blank, and to give references to three "influential persons" who know him. A deposit of $\$ 25$ is required for the reservation of a room. The deposit is returned at the end of the school year if the student's record is clear.

Dignity of labor is emphasized at the Carbon County dormitories. Every student must render one hour of service each day toward keeping the buildings in order. One mother objected to this. She offered to pay more than $\$ 20$ per month if her daughter could be excused from menial labors. The dean replied, "If that is how you feel, this dormitory is no place for your daughter."

A complete outline of work sets forth the services rendered by both the boys and the girls. These duties are assigned by the dean in advance, and are posted on a bulletin board in the respective halls at the beginning of each month.

The different assignments follow a rotation plan, so that each member of the group shares alike in the distribution. The work may extend over a week or longer, depending on its nature. It is so organized that the student can do any task assigned in the appointed time in case no dawdling is indulged in. Each has a definite task to perform daily.

The work of each assignment is outlined in detail, so that the student may understand fully the work in hand and may check up with himself before the work is inspected.

The authorities of the Carbon County High School believe in selling education. Every effort is made to acquaint the people of the county with the one high school which they support. Last year the faculty made trips over the 
county in the interests of the high school. They made a survey of all eighth-grade students. Meetings were held with these prospective students, in which the advantages of a high-school education were discussed. The faculty went to the homes of these students and discussed the subject with their parents. All the principals in the county brought their eighth-grade students to Price for a visit to the county high school and the dormitories. The campaign proved effective. Four mining camps sent students into the county high school for the first time last fall. The present enrollment is $\mathbf{3 1 7}$. One-third of this number come from outside of Price. Those who do not live at the dormitories either drive back and forth or live in private homes or live with their parents who have moved into town for the school season.

Appomattox Agricultural High School, Appomattox, Va.

[Visited November 22, 1920.]

This was formerly one of the congressional district high schools of Virginia. When the congressional district high schools were abandoned, the county board of education of Appomattox County took over the management of this school. The school plant comprises 12 acres of ground, an academic building, a dormitory, and two small cottages used as rooming houses for the boys who can not be accommodated in the dormitory.

The dormitory is a modern brick structure, which was built in 1914 at a cost of $\$ 12,000$. The principal and his family, three women teachers, the boarding girls, and some of the boarding boys live in this dormitory. Students' rooms are equipped with table, chairs, iron bedsteads, and mattresses. Students are asked to bring from home sheets, pillow slips, blankets, towels, soap, and table napkins. A charge of $\$ 25$ each for the entire school year is made for rooms for students who are residents of the county. Those outside the county are charged $\$ 50$. At present the dormitory and cottages are filled to their capacity. In the dormitory are housed 18 boys and 10 girls, and 16 boys live in the cottages.

The dining room and kitchen are in the basement of the dormitory. Meals are furnished at the cost of food, its preparation, and service. In October the cost on a pro rata basis was $\$ 18.85$ for the month. The dining room accommodates 60 persons. The vegetables raised in the garden in connection with the school and the pigs and the chickens contribute to the supply of food.

The small farm and the dormitory furnish a means of employment for students who wish to earn a part of their expenses. Two girls earn half their living expenses by sweeping and dusting. Eleven boys receive each $\$ 10$ per month-10 boys for caring for the crops and 1 boy for firing the dormitory furnace. Another boy receives half his expenses for caring for the pigs and poultry.

One of the men teachers rooms in one of the cottages and has supervision over the boys in both cottages. The matron and three women teacher assistants have similar responsibilities in the dormitory. Literary societies, class parties, and a school Y. M. C. A. furnish the social and religious life of the school. Ministers in the town make an effort to secure the attendance of students at their respective churches.

The present high-school enrollment is 117. Of the students, 45 live in the dormitories, 15 room in private homes, and 50 are transported. Appomattox County contains 342 square miles. There are two other accredited high schools in the county. Until there are better roads and more consolidated schools the dormitory feature of this school will continue to provide a means for high- 
school education for country children who live too far away to drive back and forth. The opinion was expressed that this high school might well become a senior high school and as such it might always need dormitories.

\section{BIBLIOGRAPHY.}

The number of printed references on dormitories and their problems as related to public high schools is limited. The few that are available are appended herewith:

Cromwell, A. M. The dormitory dilate. The Intermountain educator, June, 1920, pp. 451-453.

High school dormitories. Montana school bulletin, $2: 2$, January, 1920. Published by the State department of public instruction, Helena, Mont.

Hughes, Richard Cecil. Factors in the dormitory problem. Religious education, 4: 4750, April, 1909.

Jensen, George C. Sham student government. The Sierra educational news, 16: 490-91, October, 1920.

Lange, D. Dormitories at public high schools. School review, 28: 488-89, September, 1920.

Lathrop, Edith A. Dormitories for students of public secondary schools. School life, 6 : 1, 10, February 1, 1921.

- Dormitories in connection with public secondary schools. School review, 29 : 305-9, April, 1921.

Monroe, Paul. Cyclopedia of education. Boarding schools, 1: 405-408.

Porter, Noah. The dormitory system. In his American colleges and the American public. New York, Charles Scribner's sons, 1878, pp. 184-190.

School dormitories. Sixteenth Biennial Report of the Superintendent of Public Instruction of Montana. 1920, pp. 75-77.

Solving the rural school problem in sparsely settled sections-Dormitory schools in Montana. In Rural education, 1 : 19-21, March, 1920. Published by Northern Normal and Industrial School, Aberdeen, S. Dak.

Talbot, Marion. Moral and religious influence as related to environment of student life. Dormitory life for college women. Religious education, 4: 41-46, April, 1920.

Vocational agriculture in Virginia. Annual Report of the Superintendent of Public Instruction of the Commonwealth of Virginia, 1917-18, pp. 48-49. 



